\title{
Annotated catalogue of the types of Ampullariidae (Mollusca, Gastropoda) in the Muséum national d'Histoire naturelle, Paris, with lectotype designations
}

\author{
Robert H. COWIE \\ Center for Conservation Research and Training, \\ Pacific Biosciences Research Center, University of Hawaii, \\ 3050 Maile Way, Gilmore 408, Honolulu, Hawaii 96822 (USA) \\ cowie@hawaii.edu \\ Virginie HÉROS \\ case postale 51, 57 rue Cuvier, F-75231 Paris cedex 05 (France) \\ malaco@mnhn.fr
}

Muséum national d'Histoire naturelle, Département Systématique \& Évolution,

KEY WORDS

Caenogastropoda,

types,

MNHN,

nomenclature,

apple snails,

taxonomy,

freshwater,

lectotypification.
Cowie R. H. \& Héros V. 2012. - Annotated catalogue of the types of Ampullariidae (Mollusca, Gastropoda) in the Muséum national d'Histoire naturelle, Paris, with lectotype designations. Zoosystema 34 (4): 793-824. http://dx.doi.org/10.5252/z2012n4a8

\section{ABSTRACT}

The caenogastropod family Ampullariidae Gray, 1824 is a family of freshwater snails predominantly distributed in humid tropical and sub-tropical habitats in Africa, South and Central America and Asia. They include the largest of all freshwater snails and frequently constitute a major portion of the native freshwater mollusc faunas of these regions. Ampullariid taxonomy is confused, primarily because most species were described on the basis only of shell morphology, which is highly variable within species yet relatively conservative among species within the family. The need for rigorous taxonomic treatment of the group is acute and the basis for such research is comprehensive study of type material. With type material of 56 nominal species-group taxa belonging to the genera Afropomus Pilsbry \& Bequaert, 1927, Asolene d'Orbigny, 1838, Lanistes Montfort, 1810, Marisa Gray, 1824, Pomacea Perry, 1810, Pomella Gray, 1847 and Pila Röding, 1798 (31 from the New World, 14 from Africa, 11 from Asia) the Muséum national d'Histoire naturelle, Paris (MNHN), holds one of the largest collections of ampullariid type material, for which we provide this annotated catalogue. To stabilise the nomenclature, we designate lectotypes for 24 species-group taxa. Two new synonymies are established: Ampullaria castelnaudii Hupé, 1857 with Ampullaria insularum d'Orbigny, 1835, and Ampullaria elegans d'Orbigny, 1835 with Helix platae Maton, 1811. 
MOTS CLÉS

Caenogastropoda,

types,

MNHN,

nomenclature,

ampullaires,

taxonomie,

eau douce,

lectotypification.

\section{RÉSUMÉ}

Catalogue annoté des types d'Ampullariidae (Mollusca, Gastropoda) du Muséum national d'Histoire naturelle, Paris, avec désignation de lectotypes.

Les Ampullariidae Gray, 1824 constituent une famille de caenogastropodes habitant les eaux douces des régions tropicales d'Afrique, d'Amérique centrale et du Sud, et d'Asie. Elle inclut les plus gros gastéropodes d'eau douce et représente souvent l'un des principaux compartiments de la malacofaune dulçaquicole indigène de ces régions. La taxonomie des ampullaires est fluctuante, principalement du fait que la plupart des espèces ont été décrites uniquement sur la base de la morphologie des coquilles, qui est à la fois très variable au sein d'une même espèce et relativement stable entre espèces. L'examen approfondi du matériel type est un préalable à toute révision taxonomique robuste de la famille. Avec le matériel type de 56 taxons nominaux du niveau espèce appartenant aux genres Afropomus Pilsbry \& Bequaert, 1927, Asolene d'Orbigny, 1838, Lanistes Montfort, 1810, Marisa Gray, 1824, Pomacea Perry, 1810, Pomella Gray, 1847 et Pila Röding, 1798 (31 du Nouveau Monde, 14 d'Afrique et 11 d'Asie), le Muséum national d'Histoire naturelle, Paris (MNHN) possède l'une des plus importantes collections de matériel type d'ampullaires, dont nous présentons le catalogue annoté. Pour stabiliser la nomenclature, nous désignons des lectotypes pour 24 noms du niveau espèce. Deux synonymies nouvelles sont établies : Ampullaria castelnaudii Hupé, 1857 avec Ampullaria insularum d'Orbigny, 1835, et Ampullaria elegans d'Orbigny, 1835 avec Helix platae Maton, 1811.

\section{INTRODUCTION}

The caenogastropod family Ampullariidae Gray, 1824 (junior synonym Pilidae Preston, 1915 - Cowie 1997; ICZN 1999a; Bouchet \& Rocroi 2005), within the superfamily Ampullarioidea Gray, 1824, is placed in the informal group Architaenioglossa Haller, 1892, which also includes the Cyclophoroidea Gray, 1847 and Viviparoidea Gray, 1847 (Bouchet \& Rocroi 2005). The Campaniloidea Douvillé, 1904 are closely related, but the relationships among the four family-groups are unresolved (Ponder \& Lindberg 1997; McArthur \& Harasewych 2003; Strong 2003; Simone 2004; Colgan et al. 2007; Jørgensen et al. 2008; Ponder et al. 2008; Hayes et al. 2009a).

Ampullariidae are freshwater snails predominantly distributed in humid tropical and sub-tropical habitats in Africa, South and Central America and Asia. They include the largest of all freshwater snails (Pomacea maculata Perry, 1810 can attain at least $17 \mathrm{~cm}$ in adult shell height - Cowie $e t$ al.
2006) and frequently constitute a major portion of the native freshwater mollusc faunas of these regions. Of 14 neotropical freshwater snail families, Ampullariidae comprise c. $20 \%$ of the species (Strong et al. 2008).

Within the Ampullariidae, Berthold (1991: 245250) recognised 10 genera (and three subgenera) with approximately 120 species. One of these genera, Pseudoceratodes Wenz, 1928 (African, fossil only), was included in the family only tentatively. The great majority of the species are referred to just three genera: Lanistes Montfort, 1810 (Africa, including Madagascar), with just over 20 species (Berthold 1991), Pila Röding, 1798 (Ampullaria Lamarck, 1799 and Ampullarius Montfort, 1810 are junior synonyms - Cowie 1997; ICZN 1999a) (Africa and Asia), with about 30 species (Berthold 1991), and Pomacea Perry, 1810 (South and Central America) with about 50 species (Berthold 1991) but 117 nominally valid species recognised by Cowie $\&$ Thiengo (2003). The remaining six 
genera contain only one or a few species: Afropomus Pilsbry \& Bequaert, 1927 and Saulea Gray, 1868 are African; Asolene d'Orbigny, 1838, Felipponea Dall, 1919, Pomella Gray, 1847 and Marisa Gray, 1824 are South American.

Taxonomy within the family is confused and complicated (e.g., Cowie et al. 2006) and delimitation of the genera and assignment of species to genera is in some cases uncertain or incorrect and in need of revision (Hayes et al. 2009a). This is primarily because most species were described on the basis only of shell morphology, which is highly variable within species yet relatively conservative among species, such that the variable shell morphology of many species appears to overlap that of others. In the light of this confusion and the need for rigorous taxonomic research it is crucial to study type material. Ascertaining the location of type material and its correct status is the necessary first step.

The two largest museum collections of ampullariid type material are probably the Natural History $\mathrm{Mu}$ seum, London, and the Muséum national d'Histoire naturelle, Paris (MNHN). Other major ampullariid collections include: the Museum für Naturkunde der Humboldt-Universität, Berlin, its ampullariid type material catalogued by Köhler \& Glaubrecht (2006); the Zoologische Staatssammlung München, its ampullariid type material dominated by the collections of Spix, whose material was catalogued by Fechter (1983) and discussed briefly by Cowie et al. (2004); the Museo Nacional de Historia Natural, Santiago, Chile, its ampullariid type material dominated by the collections of Philippi; the Academy of Natural Sciences of Philadelphia; and the Museum of Comparative Zoology, Harvard University. Many other museums house additional type material, as exemplified by the repositories of New World ampullariid types listed by Cowie \& Thiengo (2003). The purpose, then, of the present catalogue is to document the type material of Ampullariidae housed in the Muséum national d'Histoire naturelle, Paris.

\section{MATERIAL AND METHODS}

In this catalogue, taxa are arranged alphabetically by species-group name. The name and original combination are given following the name, and are followed by the bibliographic details of the original description. Bibliographic details of subsequent publications bearing directly on the original description are provided, as necessary for clarification, in square brackets. The type locality is as given in the original description, with the original orthography. Additional type locality information (e.g., from labels or subsequent publications) is given in square brackets, along with translations and additional information as deemed appropriate. If from labels, the information is simply given followed by the catalog number in parentheses. Catalog numbers of type material are those of lots in the mollusc collection of the Muséum national d'Histoire naturelle. The number of specimens in each lot is indicated; all specimens are dry shells unless otherwise indicated. The current taxonomic status includes generic and subgeneric placement, whether a valid taxon, and if not, the appropriate synonymy. Unless otherwise stated, generic placements and synonymies for $\mathrm{New}$ World taxa follow Cowie \& Thiengo (2003). For Old World taxa (Africa/Asia), hyperstrophic (superficially sinistral) species are placed in Lanistes, one taxon is placed in Afropomus, the remainder (with calcified opercula) are placed in Pila; there is no material of Saulea. In Remarks and in Current taxonomic status sections, species-group taxa are referred to in the generic combination of their original description. All taxa treated are listed in Appendix, with those currently considered valid highlighted in bold.

Dimensions given in the figure legends are shell height (length) in $\mathrm{mm}$, measured parallel to the columella using dial calipers.

In cases in which nomenclatural interpretations have been necessary, we have followed the fourth edition of the Code (ICZN 1999b).

\section{ABBREVIATIONS AND ACRONYMS}

NHMUK the Natural History Museum, London (former acronym BMNH);

MNHN Muséum national d'Histoire naturelle, Paris;

MHNG Muséum d'Histoire naturelle, Genève; $\operatorname{spm}(s) \quad$ specimen $(s)$;

ZSM Zoologische Staatssammlung München. 


\section{CATALOGUE OF TYPE MATERIAL OF AMPULLARIIDAE}

\section{aulanieri Deville \& Huppé, 1850, Ampullaria}

(Fig. 1A)

Ampullaria aulanieri Deville \& Huppé, 1850: 642, pl. 15, fig. 4.

Current taxonomic status. - Pomacea (Pomacea). Valid species.

TYPE SPECIMENS. - Lectotype (here designated) MNHN 23072 (ex 4492); paralectotypes MNHN 4491 (4 spms), 4492 (1 spm), 23073 (9 spms).

Type locality. - "lac de Cruz Playa, sur la rivière de l'Ucayali (Pérou)”.

\section{REMARKS}

Similar to Ampullaria bridgesii Reeve, 1856 and Pomacea diffusa Blume, 1957, but comparison of the MNHN specimens with the lectotype of Ampullaria bridgesii (NHMUK 20010487) and the holotype of Pomacea diffusa (ZSM 20011991) indicates that they are probably different from both these species, being narrower and with a longer, narrower aperture. The lectotype here selected to stabilise the name is the specimen among the former syntypes that most closely matches the original illustration.

\section{baeri Dautzenberg, 1902, Ampullaria}

(Fig. 1B)

Ampullaria baeri Dautzenberg, 1902:312, pl. 9, figs 12, 13.

Current taxonomic status. - Pomacea (Effusa). Valid species.

TYPE SPECIMEN. — Lectotype (here designated) MNHN 4493.

TYPe LOCALITY. - "Rio Mixiollo [= Misciotto; Berthold 1991: 13], province de Huallaga, Pérou”.

\section{REMARKS}

Fischer-Piette (1950) indicated a holotype (“34 mm”), which Cowie \& Thiengo (2003) and Köhler \& Glaubrecht (2006) considered to have constituted an inadvertent lectotype designation. Dautzenberg implied that his description was based on more than one specimen by his use of "parfois" ("sometimes") in reference to certain shell characters, which we interpret as meaning in some specimens. The ICZN (1999b; art. 74.5) says that: "When the original work reveals that the taxon had been based on more than one specimen [which this description does], a subsequent use of the term 'holotype' [as by Fischer-Piette (1950)] does not constitute a valid lectotype designation unless the author [i.e. Fischer-Piette (1950)], when wrongly using that term, explicitly indicated that he or she was selecting from the type series that particular specimen to serve as the namebearing type." Fischer-Piette (1950) made no such explicit indication, so his simple listing of the single specimen as the "holotype" was not a valid lectotype designation, contrary to the interpretation of Cowie \& Thiengo (2003) and Köhler \& Glaubrecht (2006). The shell is $34 \mathrm{~mm}$ maximum width, agreeing with Fischer-Piette (1950). The illustration is a little smaller and does not quite match in shape, but the labels, including one in Dautzenberg's hand, say that it is the illustrated shell. We here designate it as the lectotype to stabilise the name.

In shape, this shell (although smaller) corresponds closely to many specimens of Helix glauca Linnaeus, 1758 seen by the first author, as well as to a specimen of Nerita effusa Müller, 1774, labeled in the MNHN collections as from the Lamarck collection, and to the probable syntype of Ampullaria gevesensis Deshayes, 1838 in the MNHN type collection, both of which are synonyms of Helix glauca Linnaeus, 1758, according to Cowie \& Thiengo (2003). However, this shell (which retains its periostracum) is fairly uniformly tan in colour and has an orange peristome, features seen consistently in other non-type material and that do not appear to intergrade with other shells in the MNHN, nor with other material conventionally referred to Helix glauca Linnaeus, 1758. Although Boss \& Parodiz (1977: 116) suggested that it is probably synonymous with glauca Linnaeus, 1758, the two taxa have never been formally synonymised and are probably distinct. 


\section{begini Morlet, 1889, Ampullaria}

(Fig. 1C)

Ampullaria begini Morlet, 1889: 184, 185, pl. 8, fig. 1.

Current taXonomic Status. - Pila. Valid species.

Type SPECIMEN. - Probable syntype MNHN 4499.

Type locality. - "Le Mékong et dans tout le Cambodge".

\section{REMARKS}

The original description was based on more than one specimen ["chez les individus bien conservés"], although only one set of measurements was given. The single specimen is much smaller than the dimensions given and does not match the original illustration, so we refrain from designating it as the lectotype. However, its presence in the type collection of the Journal de Conchyliologie indicates that it is probably a syntype.

\section{belizensis Crosse \& Fischer in Fischer \& Crosse, 1888, Ampullaria}

(Fig. 1D)

Ampullaria belizensis Crosse \& Fischer in Fischer \& Crosse, 1888: [explanation of] pl. 45, figs 2, 2a-c [Crosse \& Fischer 1890: 110; Fischer \& Crosse 1890: 231, pl. 48, figs 9, 9a].

Current taxonomic status. - Pomacea (Pomacea). Synonym of Ampullaria flagellata Say, 1829 (see Cowie \& Thiengo 2003: 58).

TYPE SPECIMEN. - Holotype MNHN 5139, by monotypy (ICZN 1999b: art. 73.1.2).

TYPE LOCALITY. - [No locality given. "in coloniâ anglicâ Belize” (Crosse \& Fischer 1890: 110).]

\section{REMARKS}

Cowie \& Thiengo (2003: 58) noted five lots totaling 36 specimens (in fact there are 37 ), which they considered to be syntypes. However, the name was made available from the plate and name, i.e. based on the single shell illustrated, which is therefore the holotype by monotypy. Among the 37 specimens, one shell has "type" written on it and its label says that it is the specimen figured. It matches the illustration of Crosse \& Fischer perfectly. It is therefore the holotype. Sowerby (1909: 363) appears also to have identified this shell as the holotype. The other 36 specimens (MNHN 4455), one of which was illustrated by Fischer \& Crosse (1890: fig. 9), have no type status.

\section{bloyeti Bourguignat, 1889, Meladomus}

(Fig. 1E)

Meladomus bloyeti Bourguignat, 1889: 171.

CURRENT TAXONOMIC STATUS. — Lanistes. Valid species.

TYPE SPECIMEN. - Lectotype (here designated) MNHN 4501.

TyPe locality. - "Cours d'eau aux environs de Kondoa (Ousaghara)” [Tanzania].

\section{REMARKS}

The shell is close to the dimensions given in the original description and the label is in Bourguignat's hand, written with his characteristic purplish ink. We consider this sufficient justification to designate this specimen as the lectotype to stabilise the name.

\section{bruguieri Deshayes, 1830, Ampullaria}

(Fig. 1F)

Ampullaria bruguieri Deshayes, 1830: 32.

Current taXonomic Status. - Pila. Valid species.

TYPe LOCALITY. — "Cayenne" [French Guiana; ? error].

TYPE SPECIMENS. - Lectotype (here designated) MNHN 23074 (ex 4450); paralectotypes MNHN 4450 (2 spms).

\section{REMARKS}

The label of the lectotype, here designated to stabilise the name, identifies it as the "type de l'espèce". It is the only specimen of the three that has an operculum. The operculum is calcified and the label says " $=A$. kordofana. . Parreyss" suggesting that it is a species of Pila from Africa, specifically Sudan (see also Tillier 1980: 16; Cowie \& Thiengo 2003: 80). 


\section{carinata Olivier, 1804, Ampullaria}

(Fig. 1G)

Ampullaria carinata Olivier, 1804a: 39; 1804b: 68 [as Ampullaria carinata]; 1804c: vi [explication des planches], pl. 31, fig. 2a, b [as Cyclostoma carinata].

CURRENT TAXONOMIC STATUS. — Lanistes. Valid species.

TYPE SPECIMENS. - Lectotype (here designated) MNHN 23075 (ex 4640); paralectotypes MNHN 4640 (4 spms), 4708 (4 spms).

Type locality. - "canaux d'Égypte" ["Alexandrie” (4708), "Alexandria" (4640)].

\section{REMARKS}

Olivier's text was published in two formats (Baur \& Adler 2003): a large format (quarto) version (three volumes, with Ampullaria carinata on page 39 of the second volume) and a small format (octavo) version (six volumes, with the first and second volumes, third and fourth volumes, and fifth and sixth volumes corresponding, respectively, to the first, second and third volumes of the quarto version, and with Ampullaria carinata on page 68 of the third volume). Both versions use the genus name Ampullaria. The Atlas appeared in three parts (livraisons) corresponding to the three volumes of the quarto version and respectively with the six octavo volumes. The Atlas (second livraison), which includes an "explication des planches" and the plates themselves, uses the genus name Cyclostoma. There is no evidence that the corresponding volumes of the two versions of the text and the three parts of the Atlas were not published simultaneously (Bauer \& Adler 2003). It is therefore not possible to ascertain the original combination, Ampullaria or Cyclostoma. A label with lot 4640 is probably an original label of Olivier. To stabilise the name we therefore selected the lectotype from this lot. The specimen figured by Tillier \& Mordan (1983: pl. 5, fig. 3) is from lot 4708 .

\section{castanea Deshayes, 1830, Ampullaria}

(Fig. 1H)

Ampullaria castanea Deshayes, 1830: 31.
Current taxonomic status. - Pomacea (Effusa). Synonym of Helix glauca Linnaeus, 1758 (Cowie \& Thiengo 2003: 52).

TYPE SPECIMEN. - Lectotype (here designated) MNHN 4710 .

TYPE LOCALITY. - [No locality given. The locality on the lectotype label ("Virginie" [USA]) is certainly incorrect.]

\section{REMARKS}

The label associated with the specimen is in Deshayes' hand and says "type p. 31", which is sufficient to permit us to designate this specimen as the lectotype to stabilise the name. Cowie \& Thiengo (2003: 52) and J.-P. Pointier (pers. comm. 2008) considered Ampullaria castanea a synonym of Helix glauca Linnaeus, placing it in Pomacea (Effusa).

\section{castelnaudii Hupé, 1857, Ampullaria}

(Fig. 2A)

Ampullaria castelnaudii Hupé, 1857: 65, pl. 11, fig. 1.

Current taxonomic status. - Pomacea (Pomacea). Synonym of Ampullaria insularum d'Orbigny, 1835. N. syn.

TYPE SPECIMENS. - Lectotype (here designated) MNHN 23076; paralectotypes MNHN 4712 (6 spms).

Type LOCALity. - "le fleuve des Amazones".

\section{REMARKS}

The specimen here designated as the lectotype, to stabilise the name, corresponds closely with the description, including being very close to the dimensions given. It also corresponds closely with the illustration both in colour and size. We consider it to be the specimen figured in the original description. None of the other specimens is as large as the lectotype and none precisely matches the illustration. Hupé (1857: 66) described the shell as greenish in colour covered with a ferruginous brown sort of epidermis, which also corresponds with the lectotype, but that young individuals were of a pronounced green colour, which corresponds with the appearance of the other specimens considered here as paralectotypes. The paralectotypes and the syntypes of Ampullaria 


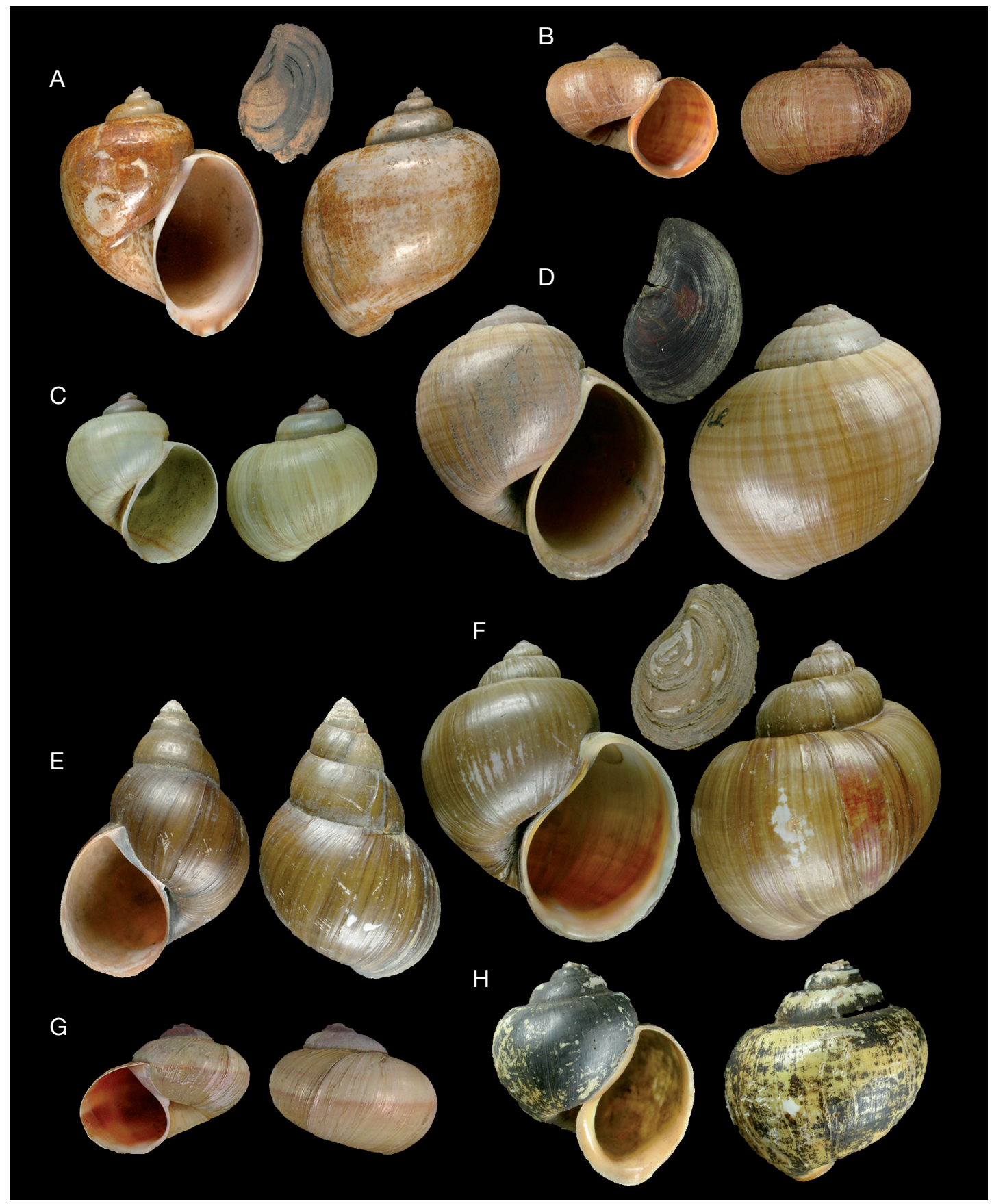

FIG. 1. - A, Ampullaria aulanieri Deville \& Huppé, 1850, lectotype MNHN 23072, 48.2 mm; B, Ampullaria baeri Dautzenberg, 1902, lectotype MNHN 4493, 27.0 mm; C, Ampullaria begini Morlet, 1889, syntype MNHN 4499, 21.4 mm; D, Ampullaria belizensis Crosse \& Fischer in Fischer \& Crosse, 1888, holotype MNHN 5139, 61.8 mm; E, Meladomus bloyeti Bourguignat, 1889, lectotype MNHN 4501, 63.3 mm; F, Ampullaria bruguieri Deshayes, 1830, lectotype MNHN 23074, 72.1 mm; G, Ampullaria carinata Olivier, 1804, lectotype MNHN 23075, 28.5 mm; H, Ampullaria castanea Deshayes, 1830, lectotype MNHN 4710, 42.2 mm. 
insularum d'Orbigny, 1835 (see below) are morphologically extremely similar and we consider them to be the same species. The holes in the shells (some of the paralectotypes but not the lectotype) were mentioned by Hupé (1857: 66) as being because they had been used to make necklaces. Similar holes are present in some of the syntypes of Ampullaria insularum. Although the lectotype itself is a different colour, it falls within the range of colours exhibited by specimens identified as Pomacea insularum (d'Orbigny, 1835) and that cluster together in a molecular analysis (Hayes et al. 2009a). We therefore consider the lectotype and paralectotypes to belong to a single species. We here synonymise Ampullaria castelnaudii with Ampullaria insularum. Cowie \& Thiengo (2003: 66) considered $A$. insularum a junior synonym of A. gigas Spix in Wagner, 1827, and others have considered $A$. gigas a junior synonym of Pomacea maculata Perry, 1810 (see Cowie \& Thiengo 2003). The type material of $A$. gigas and $P$. maculata may be lost and their synonymy, as well as the possible synonymy of $A$. insularum and $A$. castelnaudii with these two species, requires further research. Here we treat $A$. insularum as a valid species.

\section{celebensis Quoy \& Gaimard, 1834, Ampullaria} (Fig. 2B)

Ampullaria celebensis Quoy \& Gaimard, 1834: 167, pl. 57, figs 1, 2.

Current taxonomic status. - Pila. Valid species.

TYPE SPECIMENS. - Lectotype (here designated) MNHN 23077 (ex 4477); paralectotypes MNHN 4476 (1 spm), 4477 (2 spms).

Type LOCALITY. — "Manado sur l'île Célèbes" [Sulawesi].

\section{REMARKS}

The highest-spired of the four syntypes corresponds closely to the original illustrations of the shell (Quoy \& Gaimard 1834: pl. 57, figs 1, 2). The operculum also corresponds closely to the original illustrations (Quoy \& Gaimard 1834: pl. 57, figs 3, 4 ). We here designate this specimen as the lectotype to stabilise the name.

\section{chariensis Germain, 1905, Ampullaria}

(Fig. 2C)

Ampullaria chariensis Germain, 1905: 487 [1907: 232, pl. 4, fig. 10].

Current taXonomic status. - Pila. Valid species.

TYPE SPECIMEN. - Lectotype (here designated) MNHN 4478.

Type locality. - "Bas Chari, entre Bougouman et Fort-Lamy", "Le bas Chari et le lac Tchad", "le lac Tchad (Archipel Kouri)" [Chad].

\section{REMARKS}

The original label says "type". A subsequent label says "holotype" and indicates that the specimen was figured as "pl. 4 fig. 10", that is, in the later publication (Germain 1907). The labels also indicate that the shell is from the expedition material of Lacoin on which the original description was partly based. The shell is indeed that figured; it corresponds in size and the damaged outline of the peristome can be seen clearly. Although, the original description was based on more than one specimen and does not include an illustration, we designate this specimen as the lectotype to stabilise the name.

\section{chiquitensis d'Orbigny, 1838, Ampullaria}

Ampullaria chiquitensis d'Orbigny, 1838 (6 May): pl. 48, figs 10, 11 [1838 (11 June): 367].

Current taxonomic status. - Marisa. Synonym of Helix cornuarietis Linnaeus, 1758 (see Remarks).

Type SPECIMEN. - Holotype, the shell illustrated by d'Orbigny (1838: pl. 48, figs 10,11) was not found in MNHN.

Type locality. - " sud-est de la province de Chiquitos (république de Bolivia) [...] entre les Missions de SanMiguel et de San-José [...] à peu près de la première Mission, dans le lac de los Migueleños, et dans les marais des environs".

\section{REMARKS}

Although we have found no type material in the MNHN, we include this entry in our catalog in order to correct the interpretation of Cowie \& 
Thiengo (2003: 50) regarding other material in both the MNHN and NHMUK, formerly considered as syntypes. Plate 48 was published on 6 May 1838 and page 367 on 11 June 1838 (Cowie \& Thiengo 2003: 91). The plate (with name) therefore confers availability of the name from the former date. The two illustrations appear to be of the same shell, which is therefore the holotype, by monotypy. Other shells mentioned in the subsequent text are irrelevant and have no standing in nomenclature, as they were not in the publication conferring availability of the name (the plate with name). The MNHN 4479 shell, previously treated as a syntype, is not the shell illustrated; based on the banding pattern, neither is any of those in the NHMUK. Therefore, contrary to Cowie \& Thiengo (2003: $50)$, none of these specimens has any type status. Cowie \& Thiengo (2003: 50), based on previous works, treated this taxon as a synonym of Helix cornuarietis. However, based on the distributions of $M$. cornuarietis and M. planogyra Pilsbry, 1933 (Hayes 2009; Hayes et al. 2009a, b), and the type locality of Ampullaria chiquitensis, it is more likely that $A$. chiquitensis is a synonym of $M$. planogyra, although this issue requires further research and we refrain from formally synonymising them here.

\section{columbiensis Reeve, 1856, Ampullaria}

(Fig. 2D)

Ampullaria columbiensis Reeve, 1856: pl. 5, fig. 25.

Current taxonomic status. - Pomacea (Pomacea). Synonym of Ampullaria flagellata Say, 1829 (Cowie \& Thiengo 2003: 60).

TyPe SPECimens. - Syntypes MNHN 4480 (3 spms).

Type locality. — “Chiriqui, Veragua” [Colombia].

\section{REMARKS}

The name was attributed to "Sowerby, MS". However, it is not clear that Sowerby alone was responsible for both the name and the nomenclatural act satisfying the criteria of availability (ICZN 1999b: art. 50.1.1), so authorship is Reeve alone. None of these shells matches Reeve's illustration, which is clearly an illustration of one of the two shells in the NHMUK type collection. Therefore, we do not designate any of the MNHN shells as the lectotype. These specimens are from Férussac's collection but were originally from the Cuming collection, on which Reeve's description was based.

cousini Jousseaume, 1887, Ampullaria

(Fig. 2E)

Ampullaria cousini Jousseaume, 1887: 185, pl. 3, fig. 3.

Current taxonomic status. - Pomacea (Pomacea). Valid species.

TyPE SPECIMEN. - Lectotype (here designated) MNHN 4483.

Type locality. - "la République de l'Équateur" [Equador].

\section{REMARKS}

Cowie \& Thiengo (2003: 61) cited the date of publication in error as 1877 , and indicated two lots totaling three specimens, considering them all to be syntypes, as they were so indicated on their labels. However, Jousseaume indicated that only two specimens were known ("Les deux seuls exemplaires que nous connaissons de cette espèce") and the original description gives a range of measurements (e.g., height " 44 à 51 mm"). MNHN 4483 is labeled as "type figuré". This shell corresponds very well to Jousseaume's original illustration, and its measurements correspond to the smaller measurements given by him. We therefore here designate it as the lectotype to stabilise the name. Contrary to Cowie $\&$ Thiengo (2003), the two shells in MNHN 4482 cannot be considered type material because neither is large enough to be Jousseaume's second specimen.

\section{decocta Mabille, 1887, Ampullaria}

(Fig. 2F)

Ampullaria decocta Mabille, 1887a: 14 [1887b: 155].

Current taxonomic status. - Pila. Valid species.

TYPE SPECIMENS. - Lectotype (here designated) MNHN 23078 (ex 4485); paralectotype MNHN 4485. 
Type locality. - “Tonkin" [in publication title] ["Tourane" (MNHN 4485)] [Vietnam].

\section{REMARKS}

There are no illustrations in the original description of this species. Therefore, of the two shells originally in MNHN 4485, we select as the lectotype, to stabilise the name, the undamaged one that also possesses an operculum.

\section{decussata Moricand, 1836, Ampullaria}

(Fig. 2G)

Ampullaria decussata Moricand, 1836: 445, pl. 2, figs 26, 27.

Current taxonomic status. - Pomacea (Pomacea). Valid species.

Type SPECimens. - Possible syntypes MNHN 23079 (10 spms), 23080 (3 spms).

TYPe LOCALITY. — "Bahia" [Brasil; in publication title] ["Lake Baril, Brasil" (label associated with the MHNG syntypes)].

\section{elegans d'Orbigny, 1835, Ampullaria}

(Fig. 3A)

Ampullaria elegans d'Orbigny, 1835a: 33 [1841: 378].

Current taxonomic Status. - Asolene. Synonym of Helix platae Maton, 1811. N. syn.

TyPe SPECIMENS. - Syntypes MNHN 4466 (2 spms), 4467 (2 spms), 4490 (5 spms), 23081 (5 spms).

Type locality. - "Rio Piray, provincia Santa Cruz de la Sierra (republica Boliviana)" [Bolivia].

\section{REMARKS}

Listed in error in Pomacea (Pomacea) by Cowie \& Thiengo (2003: 63), as Pain (1960: 430) had synonymised it with Ampullaria cyclostoma Spix in Wagner, 1827, which they placed in Asolene. Cowie \& Thiengo (2003: 47) considered Ampullaria cyclostoma a synonym of Helix platae. We here treat Ampullaria elegans as a synonym of Helix platae. There are no illustrations in the original description with which to compare these shells. Given the uncertain status of the taxonomy of this and similar species and the possibility of mixed-species lots that require detailed taxonomic research, we refrain from selecting a lectotype from these four lots and 14 specimens.

erythrochila Dautzenberg \& Fischer, 1905, Ampullaria turbinis var.

(Fig. 3B)

Ampullaria turbinis var. erythrochila Dautzenberg \& Fischer, 1905: 428.

Current taXonomic status. - Pila. Valid species.

TyPE SPECIMEN. - Lectotype (here designated) MNHN 4738.

Type LOCAliTY. - "Cochinchine: Mékong à Chaudoc" [Vietnam].

\section{REMARKS}

The label says "TYPES" and indicates that there were two specimens. However, only one was found. We designate this remaining specimen as the lectotype to stabilise the name. The original description is minimal but says "coloration rouge du péristome". This specimen does not have a particularly red peristome. The original label was signed by Fischer.

eumicra Crosse \& Fischer, 1890, Ampullaria

(Fig. 3C)

Ampullaria eumicra Crosse \& Fischer, 1890: 113 [Fischer \& Crosse 1890: 243, pl. 48, figs 10, 10a].

Current taxonomic status. - Pomacea (Pomacea). Synonym of Ampullaria flagellata Say, 1829 (Cowie \& Thiengo 2003: 63).

TYPE SPECIMENS. - Lectotype (here designated) MNHN 23082 (ex 4489); paralectotypes MNHN 4489 (3 spms).

TYPE LOCALITY. - "provinciâ Oajaca dictâ, reipublicae Mexicanae".

\section{REMARKS}

None of the shells corresponds precisely to the dimensions given in the original description, 


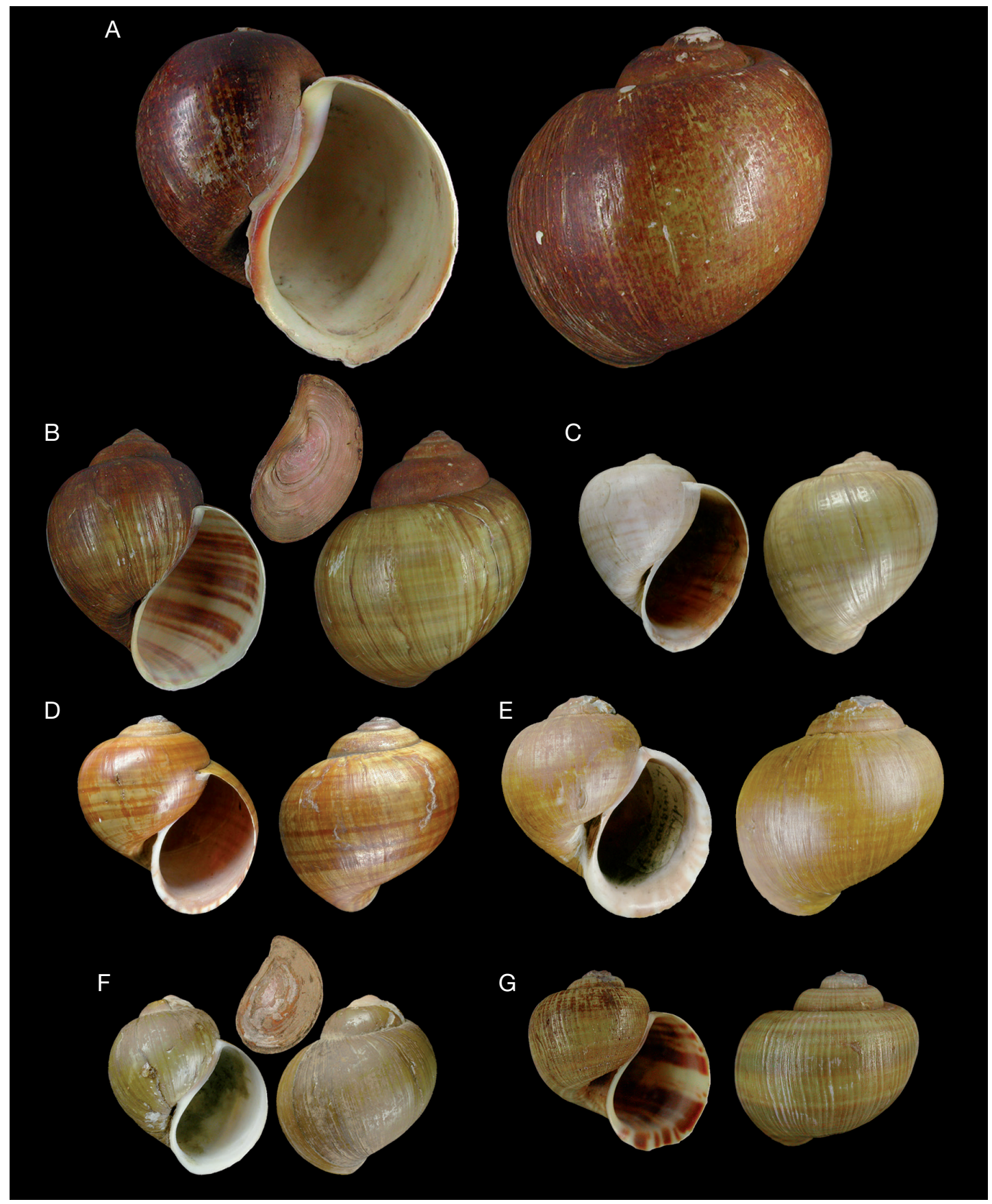

FIG. 2. - A, Ampullaria castelnaudi Hupé, 1857, lectotype MNHN 23076, 103.9 mm; B, Ampullaria celebensis Quoy \& Gaimard, 1834, lectotype MNHN 23077, 70.5 mm; C, Ampullaria chariensis Germain, 1905, lectotype MNHN 4478, 38.7 mm; D, Ampullaria columbiensis Reeve, 1856, syntype MNHN 4480, 36.8 mm; E, Ampullaria cousini Jousseaume, 1887, lectotype MNHN 4483, 43.0 mm; F, Ampullaria decocta Mabille, 1887, lectotype MNHN 23078, 29.7 mm; G, Ampullaria decussata Moricand, 1836, possible syntype MNHN 23079, $28.0 \mathrm{~mm}$. 
and the malleations that are mentioned in the description are not obvious. However, the shell on which "type" is written corresponds to the illustration in the subsequent monograph/atlas (Fischer \& Crosse 1890: pl. 48, figs 10, 10a), and we here select it as the lectotype to stabilise the name.

\section{gevesensis Deshayes, 1838, Ampullaria}

(Fig. 3D)

Ampullaria gevesensis Deshayes, 1838: 541.

Current taxonomic status. - Pomacea (Effusa). Synonym of Helix glauca Linnaeus, 1758 (Cowie \& Thiengo 2003: 54).

TyPe SPECIMEN. — Syntype MNHN 4473.

TYPE LOCALITY. — [No locality given.]

\section{REMARKS}

The shell is not as big as the dimensions given in the original description, which lacked an illustration. However, the label is in Deshayes' hand, so we consider this specimen a syntype.

\section{grasseti Morelet, 1863, Ampullaria (Lanistes)}

(Fig. 3E)

Ampullaria (Lanistes) grasseti Morelet, 1863: 267, pl. 10, fig. 2.

CURRENT TAXONOMIC STATUS. — Lanistes. Valid species.

TyPe SPECIMENS. - Probable syntypes MNHN 4457 (2 spms).

TYPe LOCALITY. — "Madagascar".

\section{REMARKS}

The two specimens do not quite correspond to the dimensions given in the original description, nor to the original illustration. Fischer-Piette (1950: 22) simply said there were two specimens, without identifying type material. However, given that they are part of the type collection of the Journal de Conchyliologie, we consider them probable syntypes. guyanensis Lamarck, 1822, Ampullaria

(Fig. 3F)

Ampullaria guyanensis Lamarck, 1822: 176.

Current taxonomic status. - Pomacea (Pomacea). Valid species.

TYPE SPECIMENS. - Paralectotypes MNHN 4458 (1 spm), 4459 (2 spms).

TYPE LOCALITY. - "les rivières de la Guyane" [French Guiana] ["Cayenne" [French Guiana] (4458), "Para" [Brasil] (4459)].

\section{REMARKS}

The lectotype, in MHNG, was designated by Tillier (1980: 27). Considered a synonym of Nerita urceus Müller, 1774 by Tillier (1980: 27), followed by Cowie \& Thiengo (2003: 65). Subsequent study (Hayes 2009) indicates that these two taxa are distinct.

\section{insularum d'Orbigny, 1835, Ampullaria}

(Fig. 3G)

Ampullaria insularum d'Orbigny, 1835a: 32 [1838: 374, pl. 51, figs 1, 2].

Current taxonomic status. - Pomacea (Pomacea). Valid species.

TyPe SPECimens. - Syntypes MNHN 4462 (2 spms), 4463 (2 spms), 5141 (1 spm).

TyPe LOCAlity. - "Rio Parana (republica Argentina)" ["Amazone" (MNHN 4462, 5141), "Rio de la Plata" (MNHN 4463)].

\section{REMARKS}

None of the shells is as large as the dimensions given in the original description. A label with MNHN 4463 says that one of the two shells was the shell figured by d'Orbigny (1838: pl. 51, figs 1, 2). However, the illustration is in fact of a much larger shell reduced to $2 / 3$ of the real size. So none of these shells can be the shell illustrated. Nonetheless, the labels say "Coll. d'Orbigny" so we consider them syntypes. Cowie \& Thiengo (2003: 66) considered Ampullaria insularum a junior synonym of Ampullaria 


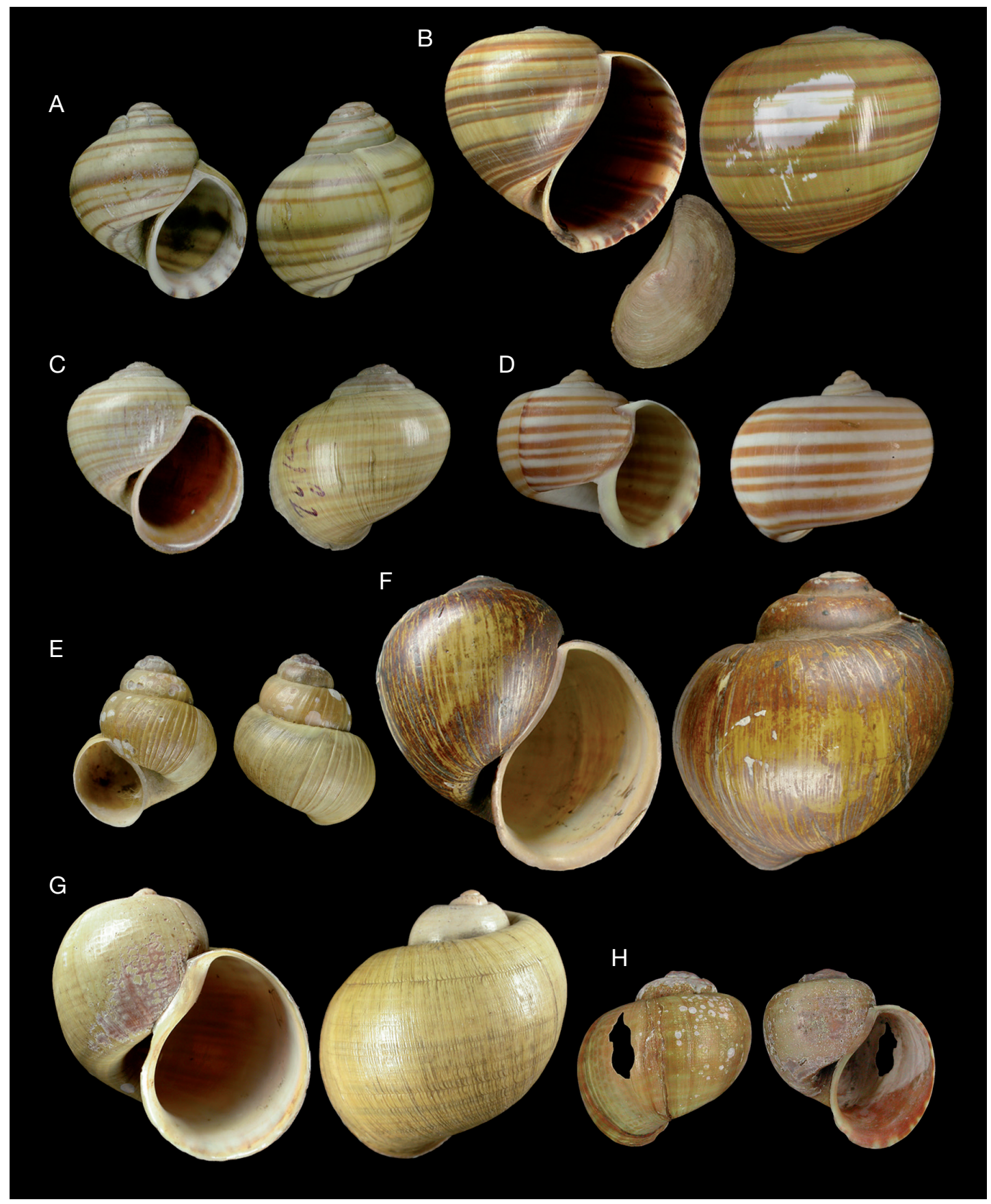

FIG. 3. - A, Ampullaria elegans d'Orbigny, 1835, syntype MNHN 23081, 31.5 mm; B, Ampullaria turbinis var. erythrochila Dautzenberg \& Fischer, 1905, lectotype MNHN 4738, 49.0 mm; C, Ampullaria eumicra Crosse \& Fischer, 1890, lectotype MNHN 23082, 29.8 mm; D, Ampullaria gevesensis Deshayes, 1838, syntype MNHN 4473, 31.9 mm; E, Ampullaria (Lanistes) grasseti Morelet, 1863, probable syntype MNHN 4457, 29.5 mm; F, Ampullaria guyanensis Lamarck, 1822, paralectotype MNHN 4459, 86.8 mm; G, Ampullaria insularum d'Orbigny, 1835, syntype MNHN 4463, 76.0 mm; H, Ampullaria intermedia Férussac in Quoy \& Gaimard, 1825, lectotype MNHN 23083, 36.0 mm. 
gigas Spix in Wagner, 1827, and others have considered Ampullaria gigas a junior synonym of Pomacea maculata Perry, 1810 (see Cowie \& Thiengo 2003). The type material of Ampullaria gigas and Pomacea maculata may be lost, so their synonymy, as well as the potential synonymy of Ampullaria insularum with these two species, requires further research. We here retain Ampullaria insularum as a distinct species, contrary to Cowie \& Thiengo (2003: 66), pending further study. Other recent studies have also continued to use Ampullaria insularum as a valid name (e.g., Rawlings et al. 2007; Barnes et al. 2008; Hayes et al. 2008, 2009a, b; Hayes 2009).

\section{intermedia Férussac \\ in Quoy \& Gaimard, 1825, Ampullaria}

(Fig. 3H)

Ampullaria intermedia Férussac in Quoy \& Gaimard, 1825: 489, pl. 68, figs 1-3.

Current taxonomic status. - Pomacea (Pomacea). Valid species.

TYPE SPECIMENS. - Lectotype (here designated) MNHN 23083 (ex 4461); paralectotype MNHN 4461.

TYPe LOCALITY. — "Brésil".

\section{REMARKS}

For an explanation of authorship of this species see comments on the original work by Cowie \& Thiengo (2003: 94). Date of publication of the description is taken as the date of publication of the text, as given by Cowie \& Thiengo (2003: 94 ), although the exact date of publication of the plate is not known. The shell in poorer condition corresponds well with the illustration in shape and in the pattern of spiral bands, but is a little smaller than the illustration. This shell is here designated as the lectotype to stabilise the name. The other shell corresponds well with Swainson's (1823: pl. 143, figs 1, 2 [top and bottom figures]) figures of Ampullaria sordida Swainson, 1823. Cowie \& Thiengo (2003: 54) considered Ampullaria intermedia a synonym of Ampullaria sordida, which they listed in Pomacea (Pomacea), yet they mistakenly listed Ampullaria intermedia in Pomacea (Effusa), which was the generic assignment followed by Berthold (1991: 23) for this species. Hayes (2009: 99), based on molecular analysis, considered it a valid species sister to Ampullaria sordida.

\section{lemniscata Crosse \& Fischer in Fischer \& Crosse, 1888, Ampullaria}

(Fig. 4A)

Ampullaria lemniscata Crosse \& Fischer in Fischer \& Crosse, 1888: [explanation of] pl. 44, figs 5, 5a-c [Crosse \& Fischer 1890: 112, 248].

Current taxonomic status. - Pomacea (Pomacea). Synonym of Ampullaria flagellata Say, 1829 (Cowie \& Thiengo 2003: 67).

Type SPECIMEN. - Holotype MNHN 4615.

TYPE LOCALITY. - [No locality given; "coloniâ anglicâ Belize” (Crosse \& Fischer 1890: 112)].

\section{REMARKS}

Cowie \& Thiengo (2003: 67) noted four specimens they considered as syntypes. However, the original publication conferring availability of Ampullaria lemniscata was an illustration (with name) of a single shell. One of the four shells has "type" written on it; a label associated with it says "type" and says that it is the shell figured; it also corresponds to the illustration very well. We consider this shell the holotype, by monotypy. The other three specimens (MNHN 5142) have no type status, contrary to Cowie \& Thiengo (2003). Sowerby (1909: 363) also reported finding type material of Ampullaria lemniscata in the MNHN.

\section{letourneuxi Bourguignat, 1879, Ampullaria} (Fig. 4B)

Ampullaria letourneuxi Bourguignat, 1879: 29.

Current taXonomic Status. - Pila. Valid species.

TYPE SPECIMEN. — Lectotype (here designated) MNHN 4614.

TYPE LOCALITY. - "Kyngani, près de Bagamoyo, lieu de départ des caravanes pour le lac de Tanganyika" "Fleuve Kyngani” [Ruvu River] (MNHN 4614)] [Tanzania]. 


\section{REMARKS}

The shell is close to the dimensions given in the original description (height $39.5 \mathrm{~mm}$, not $42 \mathrm{~mm}$; width $35 \mathrm{~mm}$, not $36 \mathrm{~mm}$ ). The MNHN is the only place Bourguignat's Tanzanian material is likely to be, and the label is in Bourguignat's hand and in the purplish ink that was highly characteristic of him. Pain (1963: 154) stated that "the type" was in the MNHN but gave no additional details sufficient to (albeit inadvertently) designate a lectotype. To stabilise the name we designate this specimen as the lectotype.

\section{libyca Morelet, 1849, Ampullaria}

(Fig. 4C)

Ampullaria libyca Morelet, 1849: 354.

CURRENT TAXONOMIC STATUS. — Lanistes. Valid species.

Type sPeCimens. - Syntypes MNHN 4610 (3 spms), 4611 (2 spms).

Type locality. - "Gabon" ["Marigots du Gabon" (MNHN 4610)].

REMARKS

MNHN 4611 has a label that indicates that the shells were received as an exchange from Morelet in 1851. Date of publication was 1849, according to Sherborn (1927).

\section{lineata Spix in Wagner, 1827, Helix}

(Fig. 4D)

Helix lineata Spix in Wagner, 1827: 3, pl. 5, fig. 2.

Current taxonomic status. - Pomacea (Pomacea). Valid species.

Type sPecimens. - Syntypes MNHN 4613 (2 spms).

Type locality. - "in aquis Provinciae Bahiensis, e.g., in fluvio Itahype" [Brasil].

\section{REMARKS}

These shells are from Férussac's collection. It is a little surprising to find types of Spix in the MNHN; perhaps they were donated to Férussac. The two shells appear to be different species on the basis of the difference in the size of the umbilicus. Further research is necessary, including assessment of type material in other collections, before either of these MNHN specimens could be designated as the lectotype. Authorship follows Cowie et al. (2004). Although Cowie \&Thiengo (2003: 64) treated Helix lineata and Ampullaria figulina Spix in Wagner, 1827 as synonyms, these two species are now considered distinct from each other (Hayes 2009: 99); and although Thiengo's paper (Thiengo 1987: 563) was about Helix "lineata", in fact it was dealing with Ampullaria figulina, as she now acknowledges (K. A. Hayes pers. comm., 14 June 2010).

luapulensis Furtado, 1886, Lanistes ellipticus var. $\gamma$

(Fig. 4E)

Lanistes ellipticus var. $\gamma$ luapulensis Furtado, 1886: 151. Current taXonomic status. - Lanistes ellipticus. Valid subspecies.

TYPE SPECIMEN. - Holotype MNHN 4714, by monotypy (ICZN 1999b: art. 73.1.2).

Type locality. - "Rivière Luapula" [Democratic Republic of the Congo, Zambia].

\section{REMARKS}

Furtado indicated only one specimen. He did not provide an illustration or size measurements but the shell matches the description in particular in terms of the partly covered umbilicus, the erosion of the spire, and the colouration, although the body whorl may be somewhat faded and has lost most of its periostracum. This and the fact that the peristome is damaged, reflect the statement that the single specimen on which the description was based was in poor condition. One of the labels says that it was part of the type collection of the Journal de Conchyliologie. We therefore consider it to be the holotype.

\section{magnus Furtado, 1886, Lanistes}

(Fig. 4F)

Lanistes magnus Furtado, 1886: 147, pl. 6, fig. 3. 
CURRENT TAXONOMIC STATUS. — Lanistes. Valid species.

TYPe SPECIMEN. - Holotype MNHN 4607, by monotypy (ICZN 1999b: art. 73.1.2).

TYPE LOCALITY. - "Rivière Luapula" [Democratic Republic of the Congo, Zambia].

\section{REMARKS}

Furtado stated that the description was based on only one specimen. The specimen corresponds very closely with the illustration and one of the labels says that it was part of the type collection of the Journal de Conchyliologie. We consider it to be the holotype, as did Fischer-Piette (1950: 155).

\section{martinezi Hidalgo, 1866, Ampullaria}

(Fig. 4G)

Ampullaria martinezi Hidalgo, 1866: 345, pl. 14, fig. 5.

Current taxonomic status. - Pomacea (Pomacea). Valid species.

TYPE SPECIMENS. - Lectotype (Fischer-Piette 1950: 68) MNHN 4608; paralectotype MNHN 4609.

TyPE LOCALITY. - “Santa-Rosa, Reipublicæ Æquatoris” [Ecuador].

\section{REMARKS}

Fischer-Piette (1950: 68) indicated a "holotype". We consider this to be a valid, though inadvertent, designation of a lectotype, as he unambiguously selected this particular specimen as the unique name-bearing type (ICZN 1999b: art. 74.5). The original description does not reveal that the taxon was based on more than one specimen, so the requirement (ICZN 1999b: second part of art. 74.5) that the author (i.e. Fischer-Piette [1950]) "explicitly indicated that he or she was selecting from the type series that particular specimen to serve as the name-bearing type" is not pertinent in this case. The other specimen mentioned by him (MNHN 4609) becomes a paralectotype. The lectotype is the shell in the original illustration, and the sizes of the two shells correspond to the sizes given by Fischer-Piette, confirming their identity. neritoides Brown \& Berthold, 1990, Lanistes

(Fig. 5A)

Lanistes neritoides Brown \& Berthold, 1990: 121-142, figs 1-10, 11a-e, 12-37.

CurRent TAXONOMIC STATUS. — Lanistes. Valid species.

Type SPECIMENS. - Holotype MNHN 4515; paratypes MNHN 4516 (20 spms, including 15 separate opercula), MNHN 4517 (28 spms, in alcohol).

Type LOCAlity. - "Region de Sounda (District de Kayes, $85 \mathrm{kms}$ au N.E. de Pointe Noire), fleuve Kouilou - affluent du Kouilou: la Mombi" [Republic of the Congo].

\section{REMARKS}

Brown \& Berthold (1990: 121, 124) indicated 52 paratypes in MNHN (25 shells, with bodies preserved separately, 23 whole animals and four bodies of sacrificed shells); there are now 49 in total (20 shells, with 15 opercula, in the dry collection, plus, in alcohol, 29 whole animals and 16 animals lacking shells). Paratypes are also in the Natural History Museum, London (NHMUK 1989.127, 2 spms; 1989.128, 2 spms, in alcohol), and the Danish Bilharziasis Laboratory, Charlottenlund (2 spms) (Brown \& Berthold 1990).

\section{neritoides d'Orbigny, 1835, Ampullaria}

(Fig. 5B)

Ampullaria neritoides d'Orbigny, 1835a: 31 [1838: 368, pl. 49, figs 1, 2].

Current taxonomic status. - Pomella (Pomella). Synonym of Ampullaria megastoma Sowerby, 1825 (Cowie \& Thiengo 2003: 78).

Type SPeCimens. - Probable syntypes MNHN 4518 (1 spm), 4519 (2 spms).

TYPE LOCALITY. - "Rio Uruguay (republica Uruguayensi orientali)" [“Corrientes" (MNHN 4518)].

\section{REMARKS}

The original description did not include an illustration. Subsequently, d'Orbigny published another description (d'Orbigny 1838: 368) followed by the associated illustrations (d'Orbigny 1838: pl. 49, figs 1, 2), of which the dates of publication were listed by Cowie $\&$ Thiengo (2003: 91). More than one specimen was 


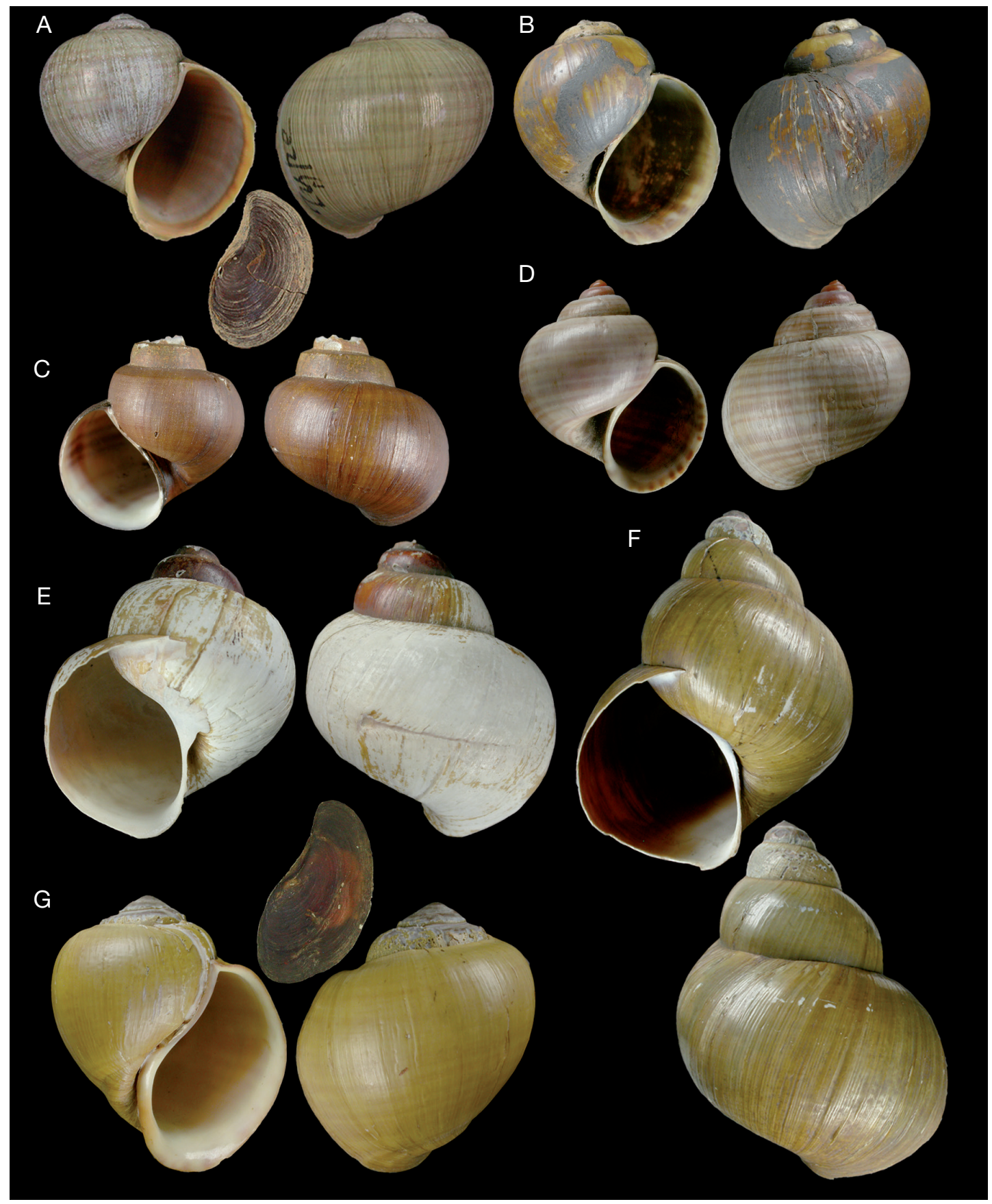

FIG. 4. - A, Ampullaria lemniscata Crosse \& Fischer in Fischer \& Crosse, 1888, holotype MNHN 4615, $41.1 \mathrm{~mm}$; B, Ampullaria letourneuxi Bourguignat, 1879, lectotype MNHN 4614, 39.5 mm; C, Ampullaria libyca Morelet, 1849, syntype MNHN 4610, 31.9 mm; D, Helix lineata Spix in Wagner, 1827, syntype MNHN 4613, 37.0 mm; E, Lanistes ellipticus var. $\gamma$ luapulensis Furtado, 1886, holotype MNHN 4714, 60.0 mm; F. Lanistes magnus Furtado, 1886, holotype MNHN 4607, 105.3 mm; G, Ampullaria martinezi Hidalgo, 1866, lectotype MNHN 4608, $56.4 \mathrm{~mm}$. 
implied in the later description. However, none of the three shells precisely matches the dimensions given in the original description, nor the illustration published subsequently, although the maximum height of the largest specimen $(100.3 \mathrm{~mm})$ is close to the value $(99 \mathrm{~mm}$ ) given in the original description. We therefore refrain from designating any of these specimens as a lectotype. Hayes (2009) and Hayes et al. (2009a, b) showed that this species groups phylogenetically among species of Pomacea, and that Pomella may not be a valid genus. We here refrain from making any formal taxonomic changes reflecting this likelihood.

\section{nimbae Binder, 1963, Afropomus balanoideus}

(Fig. 5C)

Afropomus balanoideus nimbae Binder, 1963: 13, fig. 1.

CURRENT TAXONOMIC STATUS. - Afropomus balanoideus. Valid subspecies.

TYPE SPECIMENS. - Lectotype (here designated) MNHN 4497; paralectotypes MNHN 4456 (1 spm), 4495 (5 spms, in alcohol), 4496 (1 spm), 4498 (1 spm).

Type LOCALITY. — “Dans le Gouan” [Republic of Guinea].

\section{REMARKS}

The specimen herein selected as the lectotype, to stabilise the name, is the shell on the left in figure 1 of the original description. There is a label with it that says "type" and another that says "78Ea", which ties it to the locality "Dans le Gouan" on page 11 of the original description, thereby restricting the type locality. Other localities given in the description are "Mont Nimba" [in publication title], "Nimba", "Zouguépo", "Dyé-Yé”, "Gamboué, sur la piste de Zouguépo à Sérengbara", "Yisoro, sur la piste de Zouguépo à Sérengbara", "Dans le Ya”, "Camp des gardes" and "Niomouya", all Republic of Guinea.

\section{occlusa Crosse \& Fischer in Fischer \& Crosse, 1888, Ampullaria}

(Fig. 5D)

Ampullaria occlusa Crosse \& Fischer in Fischer \& Crosse, 1888: [explanation of] pl. 45, figs 3, 3a-c [1890: 111; Fischer \& Crosse 1890: 244].
Current taxonomic status. - Pomacea (Pomacea). Synonym of Ampullaria flagellata Say, 1829 (Cowie \& Thiengo 2003: 71).

TYPE SPECIMEN. - Holotype MNHN 4514, by monotypy (ICZN 1999b: art. 73.1.2).

TyPE LOCAliTY. - [No locality given; "Tanesco, Guatemalæ" (Crosse \& Fischer 1890: 112).]

\section{REMARKS}

Cowie \& Thiengo (2003: 71) indicated 11 syntypes in two lots. However, the original publication conferring availability of Ampullaria occlusa was an illustration (with name) of a single shell. One shell, lacking an operculum, has "type" written on it and its labels say that it is the specimen figured. It corresponds very closely to the original illustration of Crosse \& Fischer. We therefore consider it to be the holotype, by monotypy. The other ten specimens (MNHN 5143), all with opercula, have no type status. Sowerby (1909: 363) also reported finding type material of Ampullaria occlusa in the MNHN.

\section{ovata Olivier, 1804, Ampullaria}

(Fig. 5E)

Ampullaria ovata Olivier, 1804a: 39; 1804b: 67; 1804c: vi [explication des planches], pl. 31, fig. 1.

Current taxonomic status. - Pila. Valid species.

TYPE SPECIMEN. - Syntype MNHN 4513.

Type LOCALITy. — “lac Maréotis” [Egypt].

\section{REMARKS}

There is no evidence that the two versions of the text and the Atlas were not published simultaneously (see Ampullaria carinata, above, for more explanation). It is therefore not possible to ascertain which constitutes the original description. The illustration is poor and it is not clear whether the shell is the actual specimen figured. We therefore refrain from designating a lectotype. The shell was also illustrated by Tillier \& Mordan (1983: pl. 5, fig. 1). 


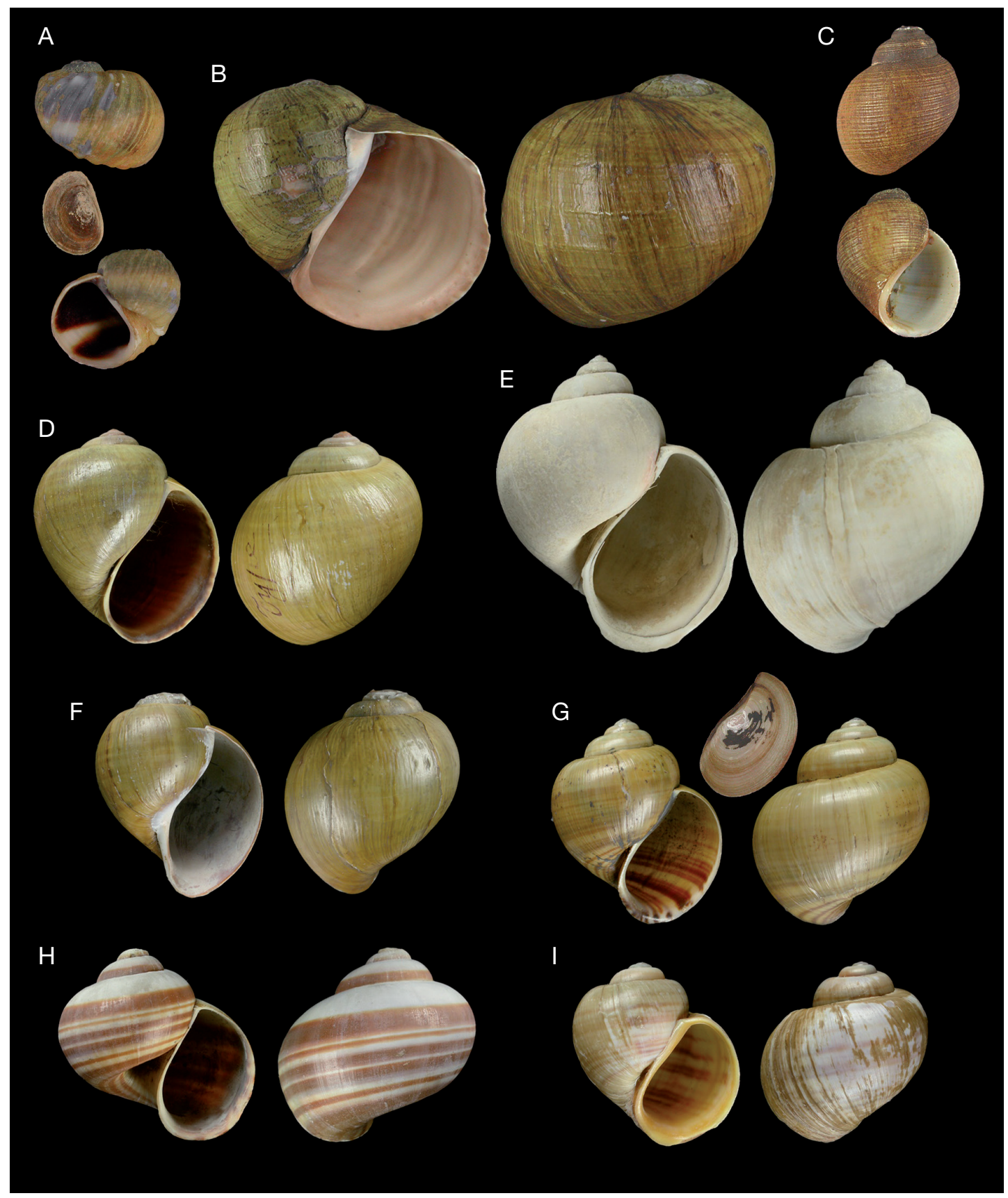

FIG. 5. - A, Lanistes neritoides Brown \& Berthold, 1990, holotype MNHN 4515, 12.9 mm; B, Ampullaria neritoides d'Orbigny, 1835, probable syntype MNHN 4519, 97.2 mm; C, Afropomus balanoideus nimbae Binder, 1963, lectotype MNHN 4497, 18.8 mm; D, Ampullaria occlusa Crosse \& Fischer in Fischer \& Crosse, 1888, holotype MNHN 4514, 49.6 mm; E, Ampullaria ovata Olivier, 1804, syntype MNHN 4513, 64.3 mm; F, Ampullaria oviformis Deshayes, 1830, syntype MNHN 4512, 43.4 mm; G, Ampullaria perakensis Morgan, 1885, lectotype MNHN 4511, 33.6 mm; H, Ampullaria peristomata d'Orbigny, 1835, syntype MNHN 4509, 38.7 mm; I, Ampullaria pesmei Morlet, 1889, lectotype MNHN 4508, $30.2 \mathrm{~mm}$. 
oviformis Deshayes, 1830, Ampullaria

(Fig. 5F)

Ampullaria oviformis Deshayes, 1830: 34.

Current taxonomic status. - Pomacea (Pomacea). Valid species.

Type SPECimens. - Syntypes MNHN 4512 (1 spm), 5285 (1 spm).

Type locality. — "Cayenne" [French Guiana; ? error; Tillier 1980: 16].

\section{REMARKS}

The two specimens are different species. Neither specimen is as large as the dimensions given in the original description ("Elle est longue de soixante millim. et large de quarante-huit"), as noted by Tillier (1980: 16). MNHN 4512 corresponds to the written description in terms of the appearance of the shell; MNHN 5285 does not, although its label says “type”. MNHN 5285 corresponds closely to syntypes of Ampullaria rufilineata Reeve, 1856 (NHMUK), but correct taxonomic assignment of these syntypes and possible designation of a lectotype must await further research.

\section{perakensis Morgan, 1885, Ampullaria}

(Fig. 5G)

Ampullaria perakensis Morgan, 1885: 418, pl. 8, fig. 12a-d. Current taxonomic status. - Pila. Valid species.

TYPE SPECIMEN. - Lectotype (here designated) MNHN 4511.

Type locality. — "le royaume de Pérak" [Perak, Peninsular Malaysia].

REMARKS

The label indicates that this shell is from Morgan's collection; the shell matches the dimensions given in the description; and it is clearly the specimen illustrated. On this basis we designate it as the lectotype to stabilise the name.

\section{peristomata d'Orbigny, 1835, Ampullaria}

(Fig. $5 \mathrm{H}$ )

Ampullaria peristomata d'Orbigny, 1835a: 32, 33 [1838: pl. 52, figs 4-6; 1841: 378].
Current taxonomic status. - Pomacea (Pomacea). Valid species.

Type SPECimens. - Syntypes MNHN 4509 (4 spms), 4510 (2 spms).

Type Locality. - “Guarayos (republica Boliviana)”.

REMARKS

Cowie \& Thiengo (2003: 72) incorrectly cited page 33 as the first page of the description. The two lots may be two different but similar species. Furthermore, they are both clearly different from the NHMUK syntypes of this species, which have a narrow umbilicus and shell height greater than shell width. None of these MNHN shells corresponds closely to the original description (d'Orbigny 1835a: 32, 33), in particular regarding the width of the umbilicus (original description: "sub-imperforata") and in the ratio of shell height to width (original description: "Long. 40 millim., lat. 38 millim."); all have a wide umbilicus, those in MNHN 4509 having shell width greater than shell height, while those in MNHN 4510 are approximately equi-dimensional. The features noted in the original description are reiterated in the later description (d'Orbigny 1841: 378) and are clear in the later illustrations (d'Orbigny 1838 : pl. 52). None of the shells matches the illustrations. The specimens in MNHN 4509 (more depressed, larger shells) are extremely similar to the larger of the syntypes (MNHN 4523) of Ampullaria zonata d'Orbigny, 1835, although again these do not closely match the original description. Correct taxonomic assignment of these syntypes and possible designation of a lectotype must await further research.

\section{pesmei Morlet, 1889, Ampullaria}

(Fig. 5I)

Ampullaria pesmei Morlet, 1889: 185, pl. 8, fig. 2.

Current taXonomic status. - Pila. Valid species.

TYPE SPECIMEN. - Lectotype (here designated) MNHN 4508.

TYPE LOCALITY. — "Phnom-Penh (Cambodge)" [Cambodia].

\section{REMARKS}

The single specimen corresponds closely to the measurements in the original description and to the 
original illustration. On this basis we here designate it as the lectotype to stabilise the name.

\section{physis Hupé, 1857, Ampullaria}

(Fig. 6A)

Ampullaria physis Hupé, 1857: 67, pl. 12, fig. 2 [two figs].

Current taxonomic status. - Pomacea (Pomacea). Synonym of Helix lineata Spix in Wagner, 1827 (see Remarks).

TYPE SPECIMENS. - Lectotype (here designated) MNHN 23084 (ex 4507); paralectotypes MNHN 4507 (1 spm), 23085 ( 2 spms).

TYPE LOCALITY. - "le fleuve des Amazones" ["Paraguay" (MNHN 4507)].

\section{REMARKS}

All the labels say "Paraguay", but Hupé wrote "le fleuve des Amazones"; to ascertain which is correct requires further research. Hupé gave only one set of measurements but did not explicitly state that the description was based on a single shell. The largest shell is clearly the shell illustrated and corresponds to the measurements given. On this basis we here designate this specimen as the lectotype, to stabilise the name, the other specimens becoming paralectotypes. Hupé suggested that it is very close to Ampullaria canaliculata Lamarck, 1822. Cowie \& Thiengo (2003) listed it as a synonym of Helix lineata Spix in Wagner, 1827, but on the basis of the locality it may instead be a synonym of Ampullaria dolioides Reeve, 1856 (K. A. Hayes pers. comm., 29 May 2010), a possibility that requires further research.

\section{polita Deshayes, 1830, Ampullaria}

(Fig. 7D)

Ampullaria polita Deshayes, 1830: 31.

Current taXonomic Status. - Pila (Pila). Objective synonym of virescens Deshayes, 1824 (see Remarks).

TYPE SPECIMEN. - As for Ampullaria virescens Deshayes, 1824.

TyPe LOCAlity. - As for Ampullaria virescens.

\section{REMARKS}

The name Ampullaria polita Deshayes, 1830 (p. 31) was introduced as a replacement name for Ampullaria virescens Deshayes, 1824, for fear of confusing the latter with Ampullaria virens Lamarck, 1822 (p. 179). Since $A$. virens and $A$. virescens are not homonyms, $A$. polita is an unnecessary replacement name and therefore a junior objective synonym of $A$. virescens, with the same name-bearing type (ICZN 1999b: art. 72.7), the holotype, for discussion of which see Ampullaria virescens. Although labels associated with a shell from Deshayes' collection, MNHN 5145, state that it is the "type" of $A$. polita, in fact it has no nomenclatural status.

\section{prunella Hupé, 1857, Ampullaria}

(Fig. 6B)

Ampullaria prunella Hupé, 1857: 67, pl. 12, figs 4 [two figures], 4a.

CURRENT TAXONOMIC STATUS. - Unclear (see Remarks).

TYPe SPECIMENS. - Syntypes MNHN 4620 (7 spms; see also Tillier 1980: 16); possible syntype MNHN 23086.

Type locality. - "les parties centrales de l'Amérique du Sud, de Rio de Janeiro à Lima, et de Lima au Para" [in publication title] ["Cayenne" (MNHN 4620)].

\section{REMARKS}

The syntypes are labeled as from "Cayenne" [French Guiana] and the published type locality is South America. However, there are four calcified opercula associated with the specimens, which would indicate that they are not New World ampullariids. The largest shell is close to the dimensions given by Hupé and corresponds in shape, but it is smaller than the original illustration, which shows a shell with more prominent spiral color bands. Nonetheless, the description matches the shells well, especially as there are a number of rather distinctive features, including in particular the fine transverse striations and the dark brown periostracum. Therefore, it seems probable that these were indeed the shells Hupé was describing, which suggests that he was mistaken regarding their origin. However, there are other shells that are very similar to these types 


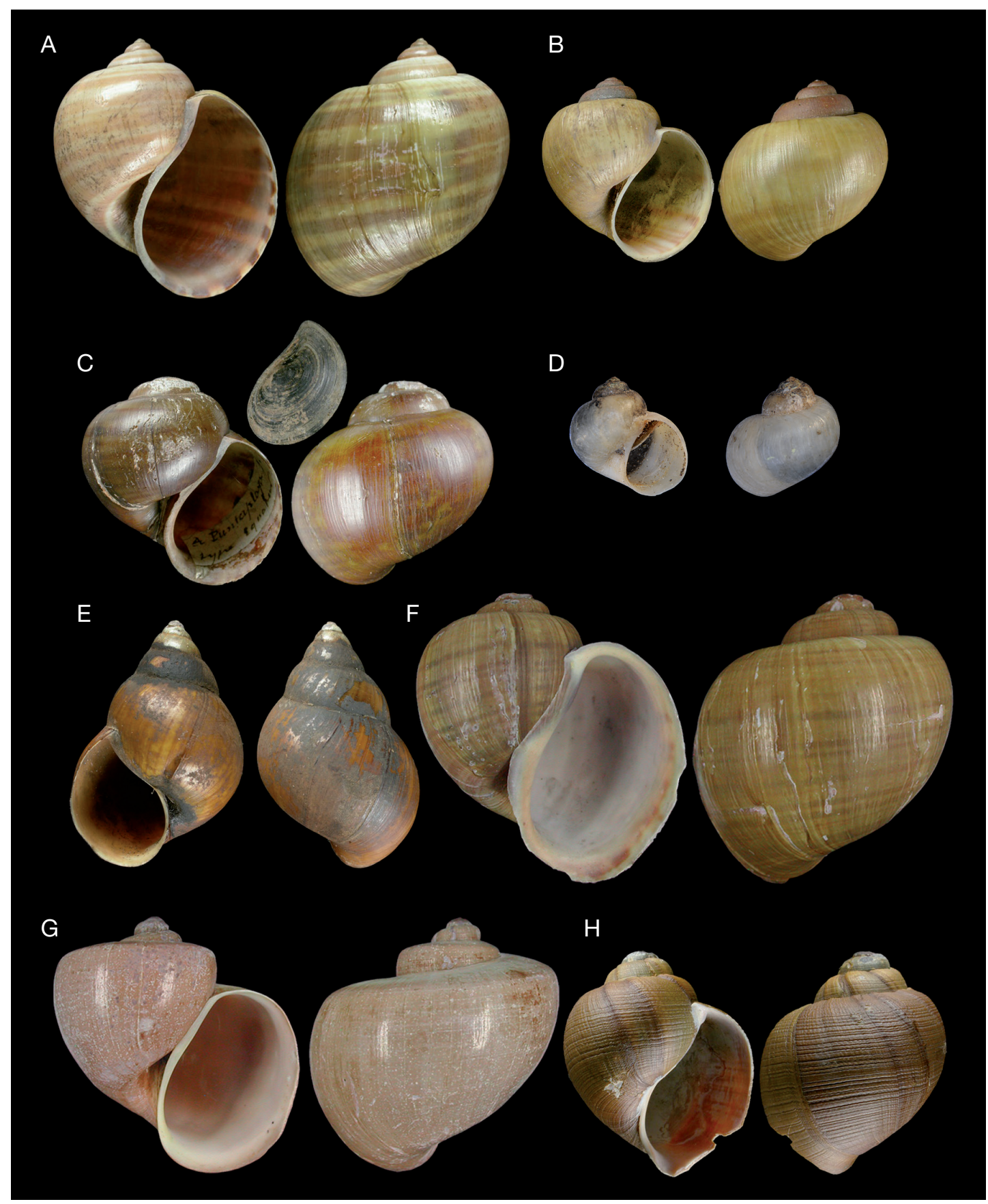

FIG. 6. - A, Ampullaria physis Hupé, 1857, lectotype MNHN 23084, 41.4 mm; B, Ampullaria prunella Hupé, 1857, syntype MNHN 4620, 25.7 mm; C, Ampullaria puntaplaya Cousin, 1887, lectotype MNHN 4622, 35.6 mm; D, Ampullaria pygmaea Récluz, 1851, syntype MNHN 4623, 7.0 mm; E, Meladomus pyramidalis Bourguignat, 1879, syntype MNHN 4624, 42.5 mm; F, Ampullaria reyrei Cousin, 1887 , possible syntype MNHN 23087, 60.3 mm; G, Ampullaria scalaris d'Orbigny, 1835, lectotype MNHN 23088, 48.9 mm; H, Ampullaria schrammi Crosse, 1876, lectotype MNHN 4630, $41.7 \mathrm{~mm}$. 


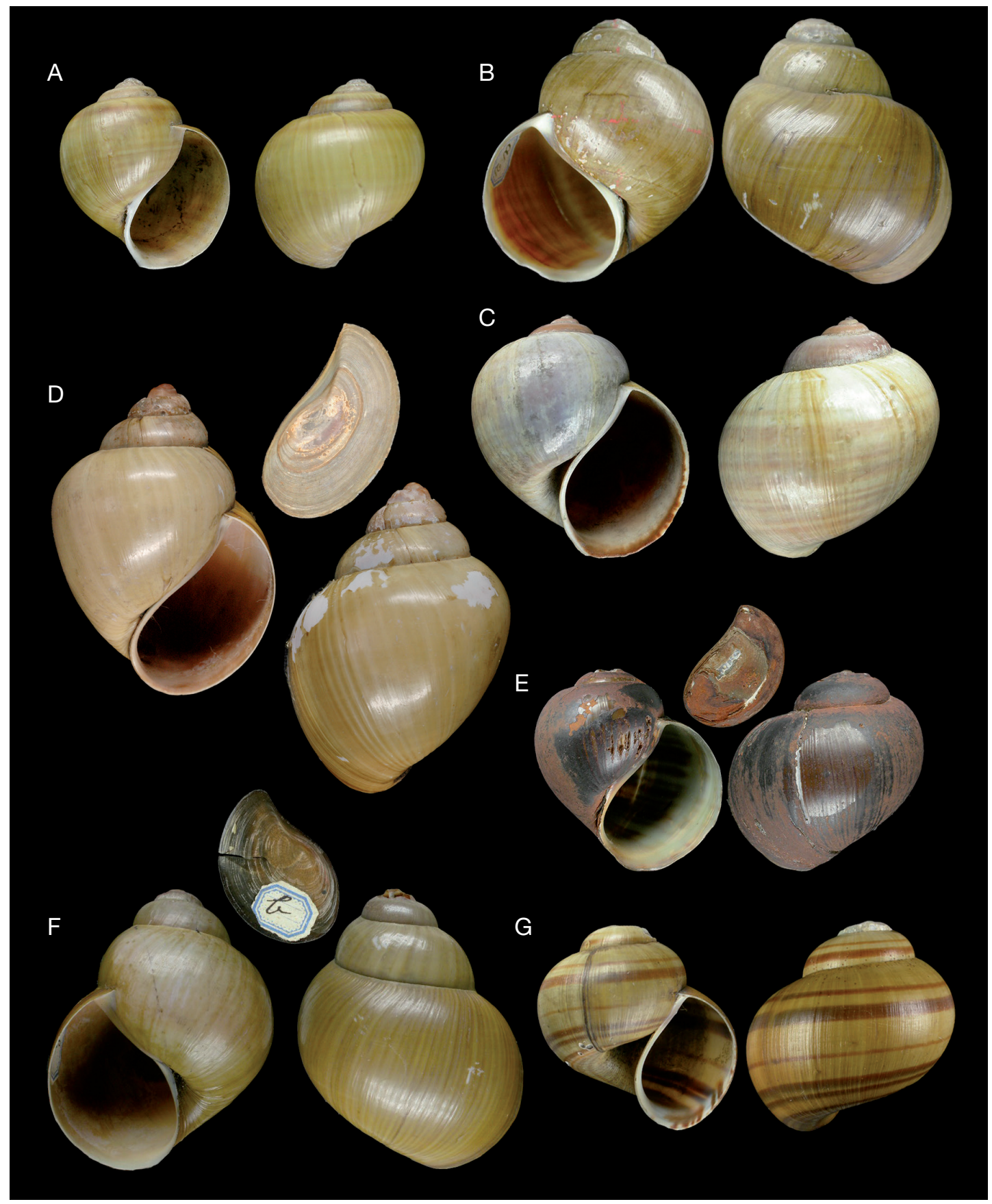

FIG. 7. - A, Ampullaria simplicula Mabille, 1889, lectotype MNHN 4520, 29.1 mm; B, Lanistes ellipticus var. $\beta$ trapeziformis Furtado, 1886, lectotype MNHN 23089, 52.8 mm; C, Ampullaria violacea Valenciennes, 1833, holotype MNHN 4530, 43.1 mm; D, Ampullaria virescens Deshayes in Bory de Saint-Vincent, 1824, holotype MNHN24513, $54.7 \mathrm{~mm}$ (also lectotype of Ampullaria polita Deshayes, 1830); E, Ampullaria wellesleyensis Morgan, 1885, lectotype MNHN 24514, 34.1 mm; F, Lanistes zambesianus Furtado, 1886, holotype MNHN 4525, 55.6 mm; G, Ampullaria zonata d'Orbigny, 1835, syntype MNHN 4523, 38.2 mm (also lectotype of Ampullaria spixii d'Orbigny, 1838). 
in the MNHN general collections (Zoothèque) also labeled as Ampullaria prunella from South America, but with no opercula. Tillier (1980: 16) suggested that these specimens represented an Asian or African species [of Pila] that had been introduced but had since disappeared from French Guiana. Given these uncertainties, we refrain from designating a lectotype.

\section{puntaplaya Cousin, 1887, Ampullaria} (Fig. 6C)

Ampullaria puntaplaya Cousin, 1887: 278, pl. 4, fig. 2. Current taxonomic status. - Pomacea (Pomacea). Valid species.

TYPE SPECIMENS. - Lectotype (here designated) MNHN 4622; paralectotypes MNHN 4621 (3 spms).

Type LOCAlity. - "Punta-Playa" ["Puntaplaya, Casa Hurtado" (MNHN 4621)] [Equador].

\section{REMARKS}

Cousin's description was explicitly based on more than one specimen. The species was not listed by Fischer-Piette (1950). One specimen (MNHN 4622) has a label inside it that says "type"; it corresponds closely to Cousin's illustration, as well as to the dimensions given in the original description; we here designate this specimen as the lectotype to stabilise the name. The other lot (MNHN 4621) contains three specimens, one of which also closely matches Cousin's illustration and the dimensions in the original description; we consider these to be paralectotypes.

\section{pygmaea Récluz, 1851, Ampullaria}

(Fig. 6D)

Ampullaria pygmaea Récluz, 1851: 216.

Current taXonomic status. - Pila. Valid species.

TyPe SPECIMENS. - Possible syntypes MNHN 4623 (2 spms).

Type locality. - "Les ruisseaux de l'île Elephanta (Bombay)" [Mumbai, India].
REMARKS

The shells match the original description and dimensions. Fischer-Piette (1950: 12) did not suggest any type status for these specimens, except that they are from the type locality (i.e. topotypes only). He figured one of them (Fischer-Piette 1950: pl. 1, fig. 7). He also indicated that they have operculae, which they do, whereas the original description said "opercule inconnu", suggesting that these may not be the original material. However, despite these inconsistencies, and inasmuch as they were in the type collection of the Journal de Conchyliologie, we consider them possibly to be syntypes. They are surely the small juveniles of a larger species.

pyramidalis Bourguignat, 1879, Meladomus

(Fig. 6E)

Meladomus pyramidalis Bourguignat, 1879: 36.

CuRrent TAXONOMIC STATUS. - Lanistes. Valid species.

Type SPecimen. - Syntype MNHN 4624.

TyPe LOCALITy. - "fleuve Kyngani, près de Bagamoyo" [Tanzania] [“Zanzibar" (MNHN 4624)].

\section{REMARKS}

Bourguignat attributed the name to "Letourneux, mss". However, it is not clear that Letourneux alone was responsible for both the name and the nomenclatural act satisfying the criteria of availability (ICZN 1999b: art. 50.1.1), so authorship is Bourguignat alone. There is nothing in the original description that allows definitive identification of this shell as type material. However, the old label is in Bourguignat's hand and favoured purple ink, and on this basis we consider this to be a syntype.

\section{reyrei Cousin, 1887, Ampullaria}

(Fig. 6F)

Ampullaria reyrei Cousin, 1887: 279, pl. 4, fig. 7.

Current taxonomic status. - Pomacea (Pomacea). Valid species.

Type SPECimen. - Possible syntype MNHN 23087. 
TyPE LOCAliTY. — Napo [Ecuador].

\section{REMARKS}

Cousin gave his collection to Jousseaume (Cousin 1887: 187; Jousseaume 1887: 165). The shell is from Jousseaume's collection. However, it is larger than the dimensions given by Cousin and it does not correspond closely with his illustration. Nevertheless, we consider that it may be a syntype.

\section{scalaris d'Orbigny, 1835, Ampullaria}

(Fig. 6G)

Ampullaria scalaris d'Orbigny, 1835a: 31 [1838: 369, pl. 50, figs 1-3].

Current taxonomic status. - Pomacea (Pomacea). Valid species.

TYPE SPECIMENS. - Lectotype (here designated) MNHN 23088 (ex 4627); paralectotypes MNHN 4626 ( 4 spms), 4627 (3 spms); possible paralectotype MNHN 4629 (1 spm, the smaller of the two shells).

Type locality. - "Rio Parana (republica Argentina) [...] Guarayos (republica Boliviana) [...] provincia Santa-Cruz de la Sierra (republica Boliviana)".

\section{REMARKS}

Some of these shells are sharply-carinate and purplish, usually considered the typical Ampullaria scalaris form, while others tend more towards less carinate, greenish and yellowish forms. Those of MNHN 4626 are close to Pomacea diffusa Blume, 1957, being less carinate. Those of MNHN 4627 (from which the lectotype here designated was selected) are typical Ampullaria scalaris. The two specimens in MNHN 4629 differ considerably from each other. One is large, pale greenish-yellowish and strongly reminiscent of Ampullaria bridgesii Reeve, 1856 (the oldest label in fact says " $A$. bridgesii"), but the other shell is of the typical Ampullaria scalaris form. The original description of the species included three varieties, although none was illustrated or named. However, the labels of MNHN 4629 identify it (presumably the larger Ampullaria bridgesii-like shell) as "var. B. major viridescens". D’Orbigny (1835a: 31) did note a "Var. B. major, viridescens" but did not formally name it. It is possible that the Ampullaria scalaris-like shell in this lot has been misplaced in this lot as it is very similar to the shells in MNHN 4627. The later illustration of d'Orbigny (1838: pl. 50) shows only the sharply-carinate, purplish form, and his account of the species (d'Orbigny 1838: 369-371) adds little to the original description. To stabilise the name, we here designate as the lectotype the largest shell among the four specimens that formerly constituted $\mathrm{MNHN}$ 4627. The remaining specimens in MNHN 4627 and those in MNHN 4626 then become paralectotypes. The larger Ampullaria bridgesii-like shell in MNHN 4629 has no type status, as we consider it to be referable to d'Orbigny's "Var. B" (see ICZN 1999b: art. 72.4.1). However, as the smaller shell in MNHN 4629 may have been misplaced in this lot, we treat it as a possible paralectotype.

\section{schrammi Crosse, 1876, Ampullaria}

(Fig. 6H)

Ampullaria schrammi Crosse, 1876: 102.

Current taxonomic status. - Pomella (Surinamia). Synonym of Bulimus sinamarina Bruguière, 1792 (Cowie \& Thiengo 2003: 78).

Type SPECIMEN. - Lectotype (Fischer-Piette 1950: 150, pl. 5, fig. 81) MNHN 4630.

Type locality. - "in flumine Oyapock, Guyanae Gallicae [Oyapok, St. George, affluent interieur au 1 er saut]" [French Guiana].

\section{REMARKS}

The shell corresponds to the dimensions given in the original description, under the presumption that "Diam. maj. 27" is a mistake and that it should be " 37 " (since the necessarily smaller "Diam. min." is given as " 35 " and 37 matches the actual dimension of this shell). Fischer-Piette (1950: 150, pl. 5, fig. 81) listed and figured a "holotype" and in so doing "unambiguously selected a particular syntype to act as the name-bearing type" (ICZN 1999b: art. 74.5), thereby validly, albeit inadvertently, designating a lectotype. The original work did not reveal "that the taxon had been based on more than one specimen" so the second part of ICZN (1999b) art. 74.5 is not pertinent. 
simplicula Mabille, 1889, Ampullaria

(Fig. 7A)

Ampullaria simplicula Mabille, 1889: 16.

Current taxonomic status. - Pila. Valid species.

Type SPECIMEN. - Lectotype (here designated) MNHN 4520.

Type locality. — “Tonkin" [in publication title] [Vietnam].

\section{REMARKS}

The shell matches the characters given in the description, but does not exactly match the dimensions. The "Diam. maj." is $28 \mathrm{~mm}$, as in the description, but the height is $29.2 \mathrm{~mm}$, not $25 \mathrm{~mm}$ as given in the description. However, this inconsistency may simply be unintentional error, and since a label in Mabille's handwriting says "type", we here designate this specimen as the lectotype to stabilise the name.

\section{spixii d'Orbigny, 1838, Ampullaria} (Fig. 7G)

Ampullaria spixii d'Orbigny, 1838: 376, pl. 52, figs 7, 8. Current taXonomic status. - Asolene. Valid species. TyPe SPECIMENS. - As for Ampullaria zonata d'Orbigny, 1835.

Type LOCALity. - As for Ampullaria zonata.

\section{REMARKS}

Valid replacement name for Ampullaria zonata d'Orbigny, 1835, non Spix in Wagner, and therefore an objective synonym of $A$. zonata, with the same name-bearing type (ICZN 1999b: art. 72.7). For details see Ampullaria zonata.

\section{trapeziformis Furtado, 1886, Lanistes ellipticus var. $\beta$}

(Fig. 7B)

Lanistes ellipticus var. $\beta$ trapeziformis Furtado, 1886: 150 .

Current taXonomic status. - Lanistes ellipticus. Valid subspecies.

TYPE SPECIMENS. - Lectotype (here designated) MNHN 23089 (ex 4713); paralectotype MNHN 4713.

Type Locality. - "Fleuve Zambèse, au dessous de Tete" [Mozambique].

\section{REMARKS}

Furtado said that the description was based on two specimens, but only one set of measurements was given and no illustration was provided. Both specimens are almost exactly the same size and correspond to the size given by Furtado. One of the labels with the less eroded specimen says "Type" and the locality above. We here select this specimen as the lectotype to stabilise the name. Furtado also gave "Rivière Cuando" as a locality, and this is written on the label of the paralectotype. The Cuando is a tributary of the Zambesi flowing from Namibia.

\section{violacea Valenciennes, 1833, Ampullaria}

(Fig. 7C)

Ampullaria violacea Valenciennes, 1833: 260.

Current taXonomic status. - Pomacea (Pomacea). Synonym of Ampullaria flagellata Say, 1829 (Cowie \& Thiengo 2003: 77).

TYPE SPECIMEN. - Holotype MNHN 4530, by monotypy (ICZN 1999b: art. 73.1.2).

TYPE LOCAliTY. - “in sylvis Americæ. (Nova Hispania.)” [Mexico].

\section{REMARKS}

The single specimen corresponds well with the figure of Fischer \& Crosse (1888[Atlas]: [explanation of] pl. 46, figs 4, 4a; 1890 [Tome 2]: 241), who considered it the "type".

\section{virescens Deshayes \\ in Bory de Saint-Vincent, 1824, Ampullaria}

(Fig. 7D)

Ampullaria virescens Deshayes in Bory de Saint-Vincent, 1824: verso of livraison cover [name and author], unnumbered plate [87], fig. 2.

Current taxonomic status. - Pila. Valid species. 
TyPE SPECIMEN. - Holotype MNHN 24513 (ex 4529), by monotypy (ICZN 1999b: art. 73.1.2).

TyPe LOCALITY. — No locality given ["Manille" [Manila, Philippines] MNHN 4529].

\section{REMARKS}

The original publication is the plate, with the name in the legend on the plate, published in the fifth livraison of plates of the Dictionnaire, with the name and authorship given on the reverse side of the front cover of the livraison. The shell illustrated is therefore the holotype by monotypy. The shell in MNHN 24513 is from Deshayes' collection and matches the shape of the shell illustrated extremely closely. We consider this to be the holotype. The other shell that was with it in the original lot (MNHN 4529), and now retains this catalog number, has no nomenclatural status.

The shell in MNHN 5145 has a label in Deshayes' hand indicating it to be the "type" of Ampullaria polita. However, it has no type status because the name $A$. polita Deshayes, 1830 (p. 31) was introduced as an unnecessary replacement name for $A$. virescens and is therefore a junior objective synonym of $A$. virescens, with the same name-bearing type (ICZN 1999b: art. 72.7). For further discussion see $A$. polita.

\section{wellesleyensis Morgan, 1885, Ampullaria}

(Fig. 7E)

Ampullaria wellesleyensis Morgan, 1885: 419, pl. 8, figs 13a-d.

Current taXonomic Status. - Pila. Valid species.

TYPE SPECIMENS. - Lectotype (here designated) MNHN 24514 (ex 4527); paralectotype MNHN 4527.

TYPE LOCALITY. - "les ruisseaux de la province Wellesley [...] aux environs de Boukit Tamboun" [Penang, Peninsular Malaysia].

\section{REMARKS}

The two specimens correspond well to the original description. The larger specimen closely matches the illustration in shape and corresponds closely, depending on the orientation of the measurements, to the actual dimensions given in the description (height $23 \mathrm{~mm}$ [error, since it cannot be smaller than the aperture height; correctly possibly $33 \mathrm{~mm}$ ], width $30 \mathrm{~mm}$, aperture height $26 \mathrm{~mm}$, aperture width $17 \mathrm{~mm}$ ), having respective dimensions of 34.6, 32.6, 26.1, $17.1 \mathrm{~mm}$. There is also a label characteristic of Morgan's collection. We therefore designate the larger of the two specimens as the lectotype to stabilise the name.

\section{zambesianus Furtado, 1886, Lanistes (Fig. 7F)}

Lanistes zambesianus Furtado, 1886: 148-150, pl. 7, figs $1,1 \mathrm{a}-\mathrm{b}$.

Current taxonomic Status. - Lanistes. Synonym of L. ellipticus Martens, 1866 (Connolly 1912: 257).

TYPE SPECIMEN. - Holotype MNHN 4525, by monotypy (ICZN 1999b: art. 73.1.2).

Type LOCAlity. - "Fleuve Zambèse, au-dessous de Tete" [Mozambique].

\section{REMARKS}

Furtado stated that the description was based on a single specimen. The specimen corresponds with the original illustration and with the size given by Furtado. Listed as the holotype by Fischer-Piette (1950: 155).

zonata d'Orbigny, 1835, Ampullaria

(Fig. 7G)

Ampullaria zonata d'Orbigny, 1835a: 32 [1838: 376, pl. 52, figs 7,8$]$.

CURRENT TAXONOMIC STATUS. - Asolene. Junior primary homonym of Ampullaria zonata Spix in Wagner, 1827; replaced by Ampullaria spixii d'Orbigny, 1838. Synonym of Ampullaria spixii d'Orbigny, 1838 (see Remarks).

Type SPeCimens. - Syntypes MNHN 4523 (3 spms), 4524 (5 spms).

Type LOCAlity. - "Rio Parana (republica Argentina) [...] Lacubus provincix Corrientes (republica Argentina)" ["Bolivie" (MNHN 4523), "Rio Securi" (MNHN 4524)]. 


\section{REMARKS}

These specimens have a wide umbilicus, as stated in the original description and as illustrated by d'Orbigny (1838: pl. 52, figs 7, 8). However, all the illustrations on pl. 52 seem to be of rather tall shells, perhaps simply not very accurate illustrations. The present specimens are very similar to the lower-spired of the syntypes of Ampullaria peristomata d'Orbigny, 1835 (MNHN 4509), but the shells of neither species correspond well with the illustrations. As a junior homonym replaced by Ampullaria spixii d'Orbigny, 1838, Ampullaria zonata d'Orbigny, 1835 is an objective synonym of Ampullaria spixii, and they have the same name-bearing type (ICZN 1999b: art. 72.7).

\section{Acknowledgements}

We thank Pierre Lozouet and M. Jean-Pierre Rocroi for bibliographic assistance, Ken Hayes, Frank Köhler and Annemarie Ohler for comments on the manuscript and Philippe Bouchet and Jean-Pierre Pointier for discussion. Alain Robin put together the plates and he and Delphine Brabant took the photographs. This work was undertaken with support in the form of MNHN Visiting Curatorships to RC, initiated by Philippe Bouchet, whom we thank for his support. RC's research on Ampullariidae is supported by the U.S. National Science Foundation, grant DEB-0949061.

\section{REFERENCES}

Barnes M. A., Fordham R. K., Burks R. I. \& Hand J. J. 2008. - Fecundity of the exotic applesnail, Pomacea insularum. Journal of the North American Benthological Society 27: 738-745.

Bauer A. M. \& AdLer K. 2003. - On the dates of publication and correct citation of Olivier's Voyage dans l'Empire Othoman and its herpetological content. Newsletter and Bulletin of the International Society for the History and Bibliography of Herpetology 4 (2): 7-18.

BERTHOLD T. 1991. — Vergleichende Anatomie, Phylogenie und historische Biogeographie der Ampullariidae (Mollusca, Gastropoda). Abhandlungen des Naturwissenschaftlichen Vereins in Hamburg (NF) 29: 1-256.

BINDER E. 1963. - La réserve naturelle intégrale du mont Nimba. I. Mollusques. Mémoires de l'Institut français d'Afrique noire 66 (5): 13-31.
Bory de SAint-Vincent [J. B. G. M.] (ed.) 1824. Dictionnaire classique d'Histoire naturelle. Planches. Cinquième livraison. Rey et Gravier, Baudouin Frères, Paris: 10 unnumbered pls and cover.

Boss K. J. \& Parodiz J. J. 1977. - Paleospecies of Neotropical ampullariids and notes on other fossil non-marine South American gastropods. Annals of Carnegie Museum 46 (9): 107-127.

BOUCHET P. \& Rocroi J.-P. 2005. - Classification and nomenclator of gastropod families. Malacologia 47: 1-397.

Bourguignat J. R. 1879. - Description de diverses espèces terrestres et fluviatiles et de différents genres de mollusques de l'Égypte, de l'Abyssinie, de Zanzibar, du Sénégal et du centre de l'A frique. Jules Tremblay, Gendre et Successeur, Paris, 54 p.

Bourguignat J. R. 1889. - Mollusques de l'Afrique équatoriale de Moguedouchou à Bagamoyo et de Bagamoyo au Tanganika. Dumoulin, Paris, 229 p., 8 pls.

BRown D. S. \& BerThold T. 1990. - Lanistes neritoides sp. n. (Gastropoda, Ampullariidae) from west Central Africa: description, comparative anatomy and phylogeny. Abhandlungen des Naturwissenschaftlichen Vereins in Hamburg (NF) 31/32: 119-152.

Colgan D. J., Ponder W. F., Beacham E. \& MacaRANAS J. 2007. - Molecular phylogenetics of Caenogastropoda (Gastropoda: Mollusca). Molecular Phylogenetics and Evolution 42: 717-737.

ConNolly M. 1912. - A revised reference list of South African non-marine Mollusca; with descriptions of new species in the South African Museum. Annals of the South African Museum 11: 59-306, pl. 2.

Cousin A. 1887. - Faune malacologique de la République de l'Équateur. Bulletin de la Société zoologique de France 12: 187-287, pls 3, 4.

CowIE R. H. 1997. — Pila Röding, 1798 and Pomacea Perry, 1810 (Mollusca, Gastropoda): proposed placement on the Official List, and Ampullariidae Gray, 1824: proposed confirmation as the nomenclaturally valid synonym of Pilidae Preston, 1915. Bulletin of Zoological Nomenclature 54 (2): 8-388.

Cowie R. H. \& Thiengo S. C. 2003. — The apple snails of the Americas (Mollusca: Gastropoda: Ampullariidae: Asolene, Felipponea, Marisa, Pomacea, Pomella): a nomenclatural and type catalog. Malacologia 45: 41-100.

Cowie R. H., Cazzaniga N. J. \& Glaubrecht M. 2004. - The South American Mollusca of Johann Baptist Ritter von Spix and their publication by Johann Andreas Wagner. The Nautilus 118: 71-87.

Cowie R. H., Hayes K. A. \& Thiengo S. C. 2006. What are apple snails? Confused taxonomy and some preliminary resolution, in JOSHI R. C. (ed.), Global Advances in Ecology and Management of Golden Apple Snails. Philippine Rice Research Institute, Muñoz, Nueva Ecija: 3-23. 
Crosse H. 1876. - Diagnosis Ampullariae novae, Guyanae Gallicae incolae. Journal de Conchyliologie 24: 102.

Crosse H. \& Fischer P. 1890. — Diagnoses Ampullariarum novarum Guatemalae et reipublicae Mexicanae incolarum. Journal de Conchyliologie 38: 110-114.

Dautzenberg P. 1902 [1901]. - Descriptions de coquilles nouvelles rapportées du Pérou par M. Baer. Journal de Conchyliologie 49: 306-313.

Dautzenberg P. \& Fischer H. 1905. - Liste des mollusques récoltés par M. H. Mansuy en Indo-Chine et au Yunnan et description d'espèces nouvelles. Journal de Conchyliologie 53: 343-471.

DeshaYes G. P. 1830-1832. - Encyclopédie méthodique. Histoire naturelle des vers. Tome second. Agasse, Paris, vii + 256 + 594 p. Volume 2 (1): i-vii, 1-256 (February 1830); volume 2 (2): 1-144 (February 1830), 145-594 (September 1832).

DeshaYes G. P. 1838. — Tome huitième. Mollusques, in Deshayes G. P. \& Milne Edwards H., Histoire naturelle des animaux sans vertèbres, présentant les caractères généraux et particuliers de ces animaux, leur distribution, leurs classes, leurs familles, leurs genres, et la citation des principales espèces qui sy rapportent; précédée d'une introduction offrant la détermination des caractères essentiels de l'animal, sa distinction $d u$ végétal et des autres corps naturels; enfin, l'exposition des principes fondamentaux de la zoologie. Deuxième édition. Revue et augmentée de notes présentant les faits nouveaux dont la science s'est enrichie jusqu'a [sic] ce jour. J. B. Baillière, Paris: 1-660.

Deville E. \& Huppé [L.] H. 1850. — Description de quelques coquilles nouvelles provenant de l'expédition de M. de Castelnau. Revue et Magasin de Zoologie pure et appliquée (2) 2: 638-644.

FECHTER R. 1983. - Liste des Typenmaterials der von J. B. v. Spix in Brasilien gesammelten Gastropoda. Spixiana supplement 9: 221-223.

Fischer P. \& Crosse H. [1870-1902]. — Recherches zoologiques pour servir à l'histoire de la faune de l'Amérique Centrale et du Mexique, publiées sous la direction de M. Milne Edwards, membre de l'Institut. Septième partie. Études sur les mollusques terrestres et fluviatiles du Mexique et du Guatemala. Imprimerie nationale, Paris, Tome 1: 702 p.; Tome 2: 731 p.; Atlas: 72 pls.

FisCHER-PieTte E. 1950. - Liste des types décrits dans le Journal de Conchyliologie et conservés dans la collection de ce journal. Journal de Conchyliologie 90: 8-23, 65-82, 149-180, pls 1-5.

FURTADO A. 1886. - Coquilles terrestres et fluviatiles de l'Exploration africaine de MM. Capello et Ivens (1884-1885). Journal de Conchyliologie 34: 138-152.

GERMAIN L. 1905. - Contributions à la faune malacologique de l'Afrique équatoriale. I. Note préliminaire sur quelques mollusques nouveaux du lac Tchad et du bassin du Chari. Bulletin du Muséum national d'Histoire naturelle 11 (6): 483-489.

GERMAIN L. 1907 [1906]. — Étude sur les mollusques recueillis par $M$. le lieutenant Lacoin, dans la région du lac Tchad. Mémoires de la Société zoologique de France 19: 219-242, pl. 4.

HAYEs K. A. 2009. - Evolution, Molecular Systematics and Invasion Biology of Ampullariidae. PhD Dissertation, University of Hawaii, Honolulu, xvi +196 p.

Hayes K. A., Joshi R. C., Thiengo S. C. \& Cowie R. H. 2008. - Out of South America: multiple origins of non-native apple snails in Asia. Diversity and Distributions 14 (4): 701-712.

HaYes K. A., Cowie R. H. \& Thiengo S. C. 2009a. - A global phylogeny of apple snails: Gondwanan origin, generic relationships and the influence of outgroup choice (Caenogastropoda: Ampullariidae). Biological Journal of the Linnean Society 98: 61-76.

Hayes K. A., Cowie R. H., Jørgensen A., SChultheiss R., Albrecht C. \& Thiengo S. C. 2009b. - Molluscan models in evolutionary biology: apple snails (Gastropoda: Ampullariidae) as a system for addressing fundamental questions. American Malacological Bulletin 27: 47-58.

HidALGO J. G. 1866. — Description d'espèces nouvelles de la République de l'Équateur. Journal de Conchyliologie 14 (4): 343-344.

Hupé [L.] H. 1857. - Animaux nouveaux ou rares recueillis pendant l'expédition dans les parties centrales de l'Amérique du sud, de Rio de Janeiro a Lima, et de Lima au Para: exécutée par ordre du gouvernement français pendant les années 1843 a [sic] 1847, sous la direction du comte Francis de Castelnau. Mollusques. P. Bertrand, Paris, 96 p., 20 pls.

INTERNATIONAL COMMISSION ON ZOOLOGICAL NoMENCLATURe (ICZN) 1999a. - Opinion 1913. Pila Röding, 1798 and Pomacea Perry, 1810 (Mollusca, Gastropoda): placed on the official list, and Ampullariidae Gray, 1824: confirmed as the nomenclaturally valid synonym of Pilidae Preston, 1915. Bulletin of Zoological Nomenclature 56: 74-76.

INTERNATIONAL COMMISSION ON ZOOLOGICAL NOMENCLATURE (ICZN) 1999b. - International Code of Zoological Nomenclature. Fourth edition. International Trust for Zoological Nomenclature, London, xxix + 306 p.

JøRGENSEN A., KRISTENSEN T. K. \& MADSEN H. 2008. A molecular phylogeny of apple snails (Gastropoda, Caenogastropoda, Ampullariidae) with an emphasis on African species. Zoologica Scripta 37 (3): 245-252.

Jousseaume F. 1887. - Mollusques nouveaux de la République de l'Équateur. Bulletin de la Société zoologique de France 12: 165-186, pl. 3.

Köhler F. \& Glaubrecht M. 2006. - The types of Ampullariidae Gray, 1824 (Mollusca, Gastropoda) in the Malacological collection of the Natural History Museum, Berlin: an annotated catalogue with 
lectotype designations. Mitteilungen aus dem Museum für Naturkunde Berlin, Zoologische Reihe 82: 201-218.

LAMARCK [J. B. P. A. DE M.] DE 1822. - Histoire naturelle des animaux sans vertèbres, présentant les caractères généraux et particuliers de ces animaux, leur distribution, leurs classes, leurs familles, leurs genres et la citation des principales espèces qui s'y rapportent, précédée d'une introduction offrant la détermination des caractères essentiels de l'animal, sa distinction $d u$ végétal et des autres corps naturels, enfin, l'exposition des principes fondamentaux de la zoologie. Tome sixième. $2^{\text {me }}$ partie. Paris, $232 \mathrm{p}$.

MABILLE J. 1887a. - Molluscorum Tonkinorum diagnoses. A. Masson, Meulan, 18 p.

Mabille J. 1887b. - Sur quelques mollusques du Tonkin. Bulletin de la Société malacologique de France 4: 73-164, pls 1-4.

MABILLE J. 1889. - Contribution à la faune malacologique $d u$ Tonkin. A. Masson, Meulan, $20 \mathrm{p}$.

McArthur A. G. \& Harasewych M. G. 2003. Molecular systematics of the major lineages of the Gastropoda, in LYDEARD C. \& LiNDBERG D. R. (eds), Molecular Systematics and Phylogeography of Mollusks. Smithsonian Institution, Washington, D.C.: 140-160.

Morelet A. [1849] [1848]. — Testacea quædam Africæ occidentalis terrestria et fluviatilia. Revue zoologique, par la Société cuvierienne 11 (12): 351-355.

MORELET A. 1863. - Description d'une espèce nouvelle. Journal de Conchyliologie 11: 267, 268, pl. 10.

MORGAN J. DE 1885. - Mollusques terrestres \& fluviatiles du royaume de Pérak et des pays voisins (presqu'île malaise). Bulletin de la Société zoologique de France 10: 353-428, 1 fold-out table.

MORICAND S. 1836. - Mémoire sur les coquilles terrestres et fluviatiles, envoyées de Bahia par M. J. Blanchet. Mémoires de la Société de Physique et d'Histoire naturelle de Genève 7 (2): 415-446, pl. 2.

Morlet L. 1889. - Catalogue des coquilles recueillies, par M. Pavie, dans le Cambodge et le Royaume de Siam et description d'espèces nouvelles. Journal de Conchyliologie 37: 121-200.

Olivier G. A. 1804a. - Voyage dans l'Empire Othoman, l'Égypte et la Perse, fait par ordre du Gouvernement, pendant les six premières années de la République. $4^{\text {to }}$ edition. Tome second. Henri Agasse, Paris, ii + 466 $+[1] \mathrm{p}$.

OLIVIER G. A. "AN 12" [1804]b. - Voyage dans l'Empire Othoman, l'Égypte et la Perse, fait par ordre du Gouvernement, pendant les six premières années de la République. $8^{\mathrm{vo}}$ edition. Tome troisième. H. Agasse, Paris, iv + $359+[1] \mathrm{p}$.

Olivier G. A. "AN XII" [1804]c. - Atlas pour servir au voyage dans l'Empire Othoman, l'Égypte et la Perse, fait par ordre du Gouvernement, pendant les six premières années de la République. Deuxième livraison. H. Agasse, Paris, vii p., pls 9, 18-33.
Orbigny A. [D.] D’ 1835a. - Synopsis terrestrium et fluviatilium molluscorum, in suo per Americam meridionalem itinere. Magasin de Zoologie 5 (61-62): $1-44$.

OrbignY A. [D.] D' 1835b-1847. - Voyage dans l'Amérique méridionale (le Brésil, la république orientale de l'Uruguay, la république Argentine, la Patagonie, la république du Chili, la république de Bolivia, la république du Pérou), exécuté pendant les années 1826 , 1827, 1828, 1829, 1830, 1831, 1832 et 1833. Tome cinquième. $3^{e}$ partie: mollusques. P. Bertrand, Paris; Ve Levrault, Strasbourg, 758 p., 82 pls. [11 June 1838: 367, 369-371, 374; 15 November 1841:378; 6 May 1838: pls 48, 52; 15 October 1838: pls 49-51.]

PaIN T. 1960. - Pomacea (Ampullariidae) of the Amazon River system. Journal of Conchology 24 (12): 421-432.

PAIN T. 1963. - Pila letourneuxi (Bourguignat), its synonymy and distribution. Journal of Conchology 25 (4): 152-155, pl. 9.

PONDER W. F. \& LindBerg D. R. 1997. — Towards a phylogeny of gastropod molluscs: an analysis using morphological characters. Zoological Journal of the Linnean Society 119: 83-265.

Ponder W. F., Colgan D., Healy J., Nützel A., Simone L. R. L. \& STRONG E. E. 2008. - Caenogastropod phylogeny, in Ponder W. F. \& LINDBERG D. R. (eds), Phylogeny and Evolution of the Mollusca. University of California Press, Berkeley: 329-382.

QuoY J. R. C. \& Gaimard J. P. 1824-[1826]. — Zoologie, in Freycinet L. C. D. de, Voyage autour du monde, entrepris par ordre du Roi sous le ministère et conformément aux instructions de S. Exc. M. le Vicomte du Bouchage, Secrétaire d'État au Département de la Marine, exécuté sur les corvettes de S. M. L'Uranie et La Physicienne, pendant les années 1817, 1818, 1819 et 1820; publié sous les auspices de S. E. M. le Comte Corbière, Secrétaire d'Etat de l'Intérieur, pour la partie historique et les sciences naturelles, et de S. E. M. le Marquis de Clermont-Tonnerre, Secrétaire d'État de la Marine et des Colonies, pour la partie nautique. Pillet Aîné, Paris, i-vii p., 1-712, 96 pls. [1825: 329-616.]

QuOY J. R. C. \& GAIMARD J. P. 1834-1835. — Voyage de découvertes de L'Astrolabe. Exécuté par ordre du Roi, pendant les années 1826-1827-1828-1829, sous le commandement de M. J. Dumont d'Urville. Zoologie. Tome troisième. J. Tastu, Paris, 954 p., pls 46-93 [mollusques], 1-20 [poissons], 1-8 [supplémentaires [sic]]. [1834: 1-366; 1835: 367-954.]

Rawlings T. A., Hayes K. A., Cowie R. H. \& Collins T. M. 2007. - The identity, distribution, and impacts of non-native apple snails in the continental United States. BMC Evolutionary Biology 7: 97 [14 p.].

RÉCLUZ C. 1851. - Description de quelques coquilles nouvelles. Journal de Conchyliologie 2: 195-216, pls 5 [part], 6 [part]. 
ReEve L. [A.] 1856. - Monograph of the genus Ampullaria, in ReEve L. [A.], Conchologia Iconica: or, Illustrations of the Shells of Molluscous Animals. Vol. X. Lovell Reeve, London: pls 1-28.

SHERBorn C. D. 1927. - Index animalium. Sectio secunda, part 14. British Museum, London: 3393-3746.

SimOnE L. R. L. 2004. — Comparative morphology and phylogeny of representatives of the superfamilies of architaenioglossans and the Annulariidae (Mollusca, Caenogastropoda). Arquivos do Museu Nacional, Rio de Janeiro 62 (4): 387-504.

Sowerby G. B. [3rd of the name] 1909. - Notes on certain types of Ampullaria in the Paris and Geneva museums. Proceedings of the Malacological Society of London 8: 363-364.

STRONG E. E. 2003. - Refining molluscan characters: morphology, character coding and a phylogeny of the Caenogastropoda. Zoological Journal of the Linnean Society 137: 447-554.

Strong E. E., Gargominy O., Ponder W. F. \& Bouchet P. 2008. — Global diversity of gastropods (Gastropoda; Mollusca) in freshwater. Hydrobiologia 595: 149-166.

SWAINSON W. 1822-1823. - Zoological Illustrations, or Original Figures and Descriptions of New, Rare, or Interesting Animals, Selected Chiefly from the Classes of Ornithology, Entomolgy, and Conchology, and Arranged on the Principles of Cuvier and Other Modern Zoologists. Vol. III. Baldwin, Cradock, and
Joy, and W. Wood, London, 63 p., pls 120-182. [1823: pls 135-192.]

THIENGO S. C. 1987. - Observations on the morphology of Pomacea lineata (Spix, 1827) (Mollusca, Ampullariidae). Memórias do Instituto Oswaldo Cruz 82 (4): 563-570.

Tillier S. 1980. — Gastéropodes terrestres et fluviatiles de Guyane française. Mémoires du Muséum national d'Histoire naturelle, nouvelle série, série A, Zoologie 118: 1-189.

Tillier S. \& Mordan P. 1983. - The conchological collections of Bruguière and Olivier from the Ottoman Empire (1792-1798). Journal of Conchology 31: 153-160.

VALENCIENNES A. 1833. - Coquilles univalves terrestres et fluviatiles, in HumboldT A. DE \& BonPland A., Recueil d'observations de zoologie et d'anatomie comparée, faites dans l'océan Atlantique, dans l'intérieur du nouveau continent et dans la mer du Sud pendant les années 1799, 1800, 1801, 1802 et 1803. Deuxième volume. J. Smith \& Gide, Paris: 238-261, pls 55-57.

WAGNER J. A. 1827. - Testacea fluviatilia quae in itinere per Brasiliam annis MDCCCXVII-MDCCCXX jussu et auspiciis Maximiliani Josephi I. Bavariae regis augustissimi suscepto collegit et pingenda curavit Dr. J. B. de Spix, quondam ordinis regii corone Bavarica civilis eques, academia scientarum Bavarice socius ordinarius, musei regii zoologici, zootomici et ethnographici conservator rel. C. Wolf, Monachii [= Munich], iv + [ii] + 36 p., 29 pls.

Submitted on 20 June 2011; accepted on 29 June 2012. 


\section{APPENDIX}

This list includes all taxa dealt with in the text, with their original generic combination or varietal status indicated in square brackets. Taxa in bold are those currently considered valid.

aulanieri Deville \& Huppé, 1850 [Ampullaria]

baeri Dautzenberg, 1902 [Ampullaria]

begini Morlet, 1889 [Ampullaria]

belizensis Crosse \& Fischer in Fischer \& Crosse, 1888

[Ampullaria]

bloyeti Bourguignat, 1889 [Meladomus]

bruguieri Deshayes, 1830 [Ampullaria]

carinata Olivier, 1804 [Ampullaria]

castanea Deshayes, 1830 [Ampullaria]

castelnaudii Hupé, 1857 [Ampullaria]

celebensis Quoy \& Gaimard, 1834 [Ampullaria]

chariensis Germain, 1905 [Ampullaria]

chiquitensis d'Orbigny, 1838 [Ampullaria]

columbiensis Reeve, 1856 [Ampullaria]

cousini Jousseaume, 1887 [Ampullaria]

decocta Mabille, 1887 [Ampullaria]

decussata Moricand, 1836 [Ampullaria]

elegans d'Orbigny, 1835 [Ampullaria]

erythrochila Dautzenberg \& Fischer, 1905 [Ampullaria turbinis var.]

eumicra Crosse \& Fischer, 1890 [Ampullaria]

gevesensis Deshayes, 1838 [Ampullaria]

grasseti Morelet, 1863 [Ampullaria (Lanistes)]

guyanensis Lamarck, 1822 [Ampullaria]

insularum d'Orbigny, 1835 [Ampullaria]

intermedia Férussac in Quoy \& Gaimard, 1825 [Ampullaria]

lemniscata Crosse \& Fischer in Fischer \& Crosse, 1888

[Ampullaria]

letourneuxi Bourguignat, 1879 [Ampullaria]

libyca Morelet, 1849 [Ampullaria]

lineata Spix in Wagner, 1827 [Helix] luapulensis Furtado, 1886 [Lanistes ellipticus var. $\gamma$ ] magnus Furtado, 1886 [Lanistes]

martinezi Hidalgo, 1866 [Ampullaria]

neritoides Brown \& Berthold, 1990 [Lanistes]

neritoides d'Orbigny, 1835 [Ampullaria]

nimbae Binder, 1963 [Afropomus balanoideus]

occlusa Crosse \& Fischer in Fischer \& Crosse, 1888

[Ampullaria]

ovata Olivier, 1804 [Ampullaria]

oviformis Deshayes, 1830 [Ampullaria]

perakensis Morgan, 1885 [Ampullaria]

peristomata d'Orbigny, 1835 [Ampullaria]

pesmei Morlet, 1889 [Ampullaria]

physis Hupé, 1857 [Ampullaria]

polita Deshayes, 1830 [Ampullaria]

prunella Hupé, 1857 [Ampullaria]

puntaplaya Cousin, 1887 [Ampullaria]

pygmaea Récluz, 1851 [Ampullaria]

pyramidalis Bourguignat, 1879 [Meladomus]

reyrei Cousin, 1887 [Ampullaria]

scalaris d'Orbigny, 1835 [Ampullaria]

schrammi Crosse, 1876 [Ampullaria]

simplicula Mabille, 1889 [Ampullaria]

spixii d'Orbigny, 1838 [Ampullaria]

trapeziformis Furtado, 1886 [Lanistes ellipticus var. $\beta$ ]

violacea Valenciennes, 1833 [Ampullaria]

virescens Deshayes in Bory de Saint-Vincent, 1824

[Ampullaria]

wellesleyensis Morgan, 1885 [Ampullaria]

zambesianus Furtado, 1886 [Lanistes]

zonata d'Orbigny, 1835 [Ampullaria] 